Rakenteiden Mekaniikka

Vol. 50, Nro 4, 2017, s. $420-450$

http://rakenteidenmekaniikka.journal.fi/index

https://doi.org/10.23998/rm.64657

(C)Kirjoittajat 2017.

Vapaasti saatavilla CC BY-SA 4.0 lisensioitu.

\title{
Metallien virumismurron ja virumisväsymisen mallintaminen
}

\author{
Petteri Kauppila, Reijo Kouhia ${ }^{1}$, Juha Ojanperä, Timo Saksala, Timo Sorjonen
}

Tiivistelmä. Artikkelissa tarkastellaan metallien korkealämpötilan virumismurron ja virumisväsymisen mallintamista. Aluksi esitetään lyhyt katsaus virumisen fysikaalisiin perusteisiin ja virumismalleihin. Käytetyn termodynaamisesti konsistentin materiaalimallin konstitutiiviset yhtälöt esitetään varsin perusteellisesti. Mallin materiaaliparametrit määritetään 7CrMoVTiB1010 teräkselle lämpötila-alueella $500-600^{\circ} \mathrm{C}$. Malli on implementoitu ANSYS elementtimenetelmäohjelmiston USERMAT-aliohjelmaksi.

Avainsanat: viruminen, väsyminen, vauriomekaniikka, termodynaaminen muotoilu

Vastaanotettu 12.6.2017. Hyväksytty 8.12.2017. Julkaistu verkossa 14.12.2017

\section{Johdanto}

Ekologinen, kestävän kehityksen mukainen energiantuotanto on yhdistelmä hyvin monimuotoisista energian lähteistä. Tästä johtuen erilaisten energiantuottomuotojen käyttö on joustavaa ja näiden toimintasyklit muodostuvat epäsäännöllisistä prosessien toimintaajoista. Täten sähköä ja lämpöä tuottavien lauhdevoimalaitoskattiloiden painerungon osat altistuvat käyttöikänsä aikana - aikaisempaa useampien - kylmäkäynnistysten, korkeiden käytönaikaisten lämpötilojen ja höyrynpaineiden sekä toisiinsa liitettyjen osien erisuuruisten lämpötilojen aiheuttamien lämpöjännitysten vuoksi yhdistetylle virumis- ja väsymiskuormitukselle, joka erityisesti voimalaitoksen kuumimmissa tulistinkammioissa voi aiheuttaa vaurioita voimalaitoksen käyttöiän aikana. Voimalaitosten tehojen ja kokojen jatkuvasti kasvaessa vaaditaan niiden suunnittelussa aiempaa tarkempaa tietoa erityisesti tulistinkammioiden virumisväsymisen syistä ja mekanismeista. Lisäksi tulistinkammioiden virumisväsymismitoitukseen tarvitaan entistä tarkempia laskentamenetelmiä, joiden perusteella voidaan määritellä yhä parempia tulistinkammioiden suunnitteluperiaatteita.

Tässä artikkelissa lähestytään virumisväsymisen mallintamista vauriomekaniikan keinoin ja vallitsevat konstitutiiviset yhtälöt johdetaan termodynaamisesti konsistentilla tavalla. Malli on ohjelmoitu kaupalliseen elementtimenetelmäohjelmaan käyttäjän määrittelemällä materiaalialiohjelmalla. Mallin vaatimat materiaaliparametrit määritetään materiaalivalmistajan tietojen perusteella ja mallia sovelletaan tulistinkammion aisan väsy-

\footnotetext{
${ }^{1}$ Vastuullinen kirjoittaja. reijo.kouhia@tut.fi
} 
misanalyysiin. Aluksi annetaan kuitenkin lyhyt yleiskatsaus höyryvoimalaitosten kattilarakenteista. Esitys perustuu Petteri Kauppilan diplomityöhön [17].

\section{Voimalaitoskattila ja tulistimet}

Suuret biopolttoaineita polttavat lauhdevoimalaitoskattilat jaetaan rakenteeltaan kerrosleiju- ja kiertoleijukattiloihin, jotka eroavat toisistaan konstruktion, polttoprosessin ja käytettävien polttoaineiden osalta. Aluksi esitellään lyhyesti kerrosleijukattilan rakenne ja toimintaperiaate sekä konkreettisen väsymis- ja virumistarkastelun kohteena olevan tulistimen rakenne sekä toimintaperiaate.

\section{Kerrosleijukattila}

Tyypillisen kerrosleijukattilan sivukuvanto on esitetty kuvassa 1. Kerrosleijukattilassa tulipesän pohjassa olevista ilmasuuttimista puhalletaan tulipesään palamisilmaa tulipesän pohjalla olevan hienojakoisen hiekkakerroksen läpi. Voimakas ilmavirtaus nostaa tulipesän pohjalla olevaa hiekkaa ylöspäin muodostaen hiekasta noin metrin korkuisen leijupedin, joka toimii polttotapahtumassa lämpöä varastoivana polttoalustana. Polttoaine syötetään tulipesään leijupedin yläpuolella olevista polttoaineensyöttöaukoista, ja hienojakoisimmat polttoainepartikkelit palavat ilmassa leijukerroksen yläpuolella heti tulipesään saavuttuaan kun taas suurikokoisimmat ja mahdollisesti kosteat polttoainepartikkelit palavat vasta leijukerroksen sisällä. Palamisessa syntyvät savukaasut nousevat tulipesässä sen yläosaan ja kulkevat sieltä kattilan tulistimien läpi kattilan toisen vedon savukaasukanavaan luovuttaen tulistimien läpi kulkiessaan lämpöä kattilan tuottamaan höyryyn ja nostaen tulistetun höyryn lämpötilaa [19, s. 17-2-17-6, 19-9].

Toisessa vedossa savukaasut kulkevat tulistimien jälkeen kattilan syöttöveden ja palamisilman esilämmittimien läpi. Näillä otetaan talteen savukaasuissa tulistimien jälkeen jäljellä olevaa lämpöenergiaa siirtäen sitä kattilaan syötettävään viileään syöttöveteen ja palamisilmaan. Syöttöveden ja palamisilman esilämmittimien jälkeen savukaasut kulkevat savukaasunkäsittelyjärjestelmien kautta savupiippuun [19, s. 20-1,20-7,34-1-34-14].

\section{Tulistin}

Lauhdevoimalaitoksissa tulistimia käytetään sähköä tuottavaa generaattoria pyörittävälle turbiinille syötettävän höyryn lämpötilan nostamiseen kylläisen höyryn lämpötilaa korkeammaksi. Tulistimia on höyrykattilassa yleensä 2-3 kappaletta ja tulistimet nimetään primääri-, sekundääri- ja tertiääritulistimiksi sen perusteella, monentenako tulistimena ne ovat kattilassa lieriön jälkeen höyryn virtaussuunnassa. Tulistinkierrossa viimeisenä olevasta tulistimesta, jossa virtaavan höyryn lämpötila on korkein, johdetaan höyry turbiinille. Tulistimilla aikaansaatu höyryn lämpötilan nosto parantaa huomattavasti Rankineprosessiin perustuvan voimalaitoksen termistä hyötysuhdetta [19, s. 19-9, 19-20]. Esimerkiksi tavanomaisella luonnonkiertoisen kerrosleijukattilan painetasolla 14,0 MPa kylläisen höyryn lämpötila on $337^{\circ} \mathrm{C}$ [33, s. 188], mutta tulistamalla turbiinille menevän päähöyryn lämpötila saadaan nostettua yli $500{ }^{\circ} \mathrm{C}$ :een, mikä kasvattaa merkittävästi höyryn entalpiaa ja siten kattilan sähkötehoa sekä hyötysuhdetta. Tässä esiteltävä tyypillinen kerrosleijukattilan riipputulistin koostuu kuvan 2 mukaisesti tulipesän ja savukaasukanavan ulkopuolella olevista jako- ja kokoojakammiosta sekä niiden välissä tulipesän tai savukaasukanavan sisällä olevista lämpöä savukaasuista ja mahdollisesti myös tulipesän polttota- 


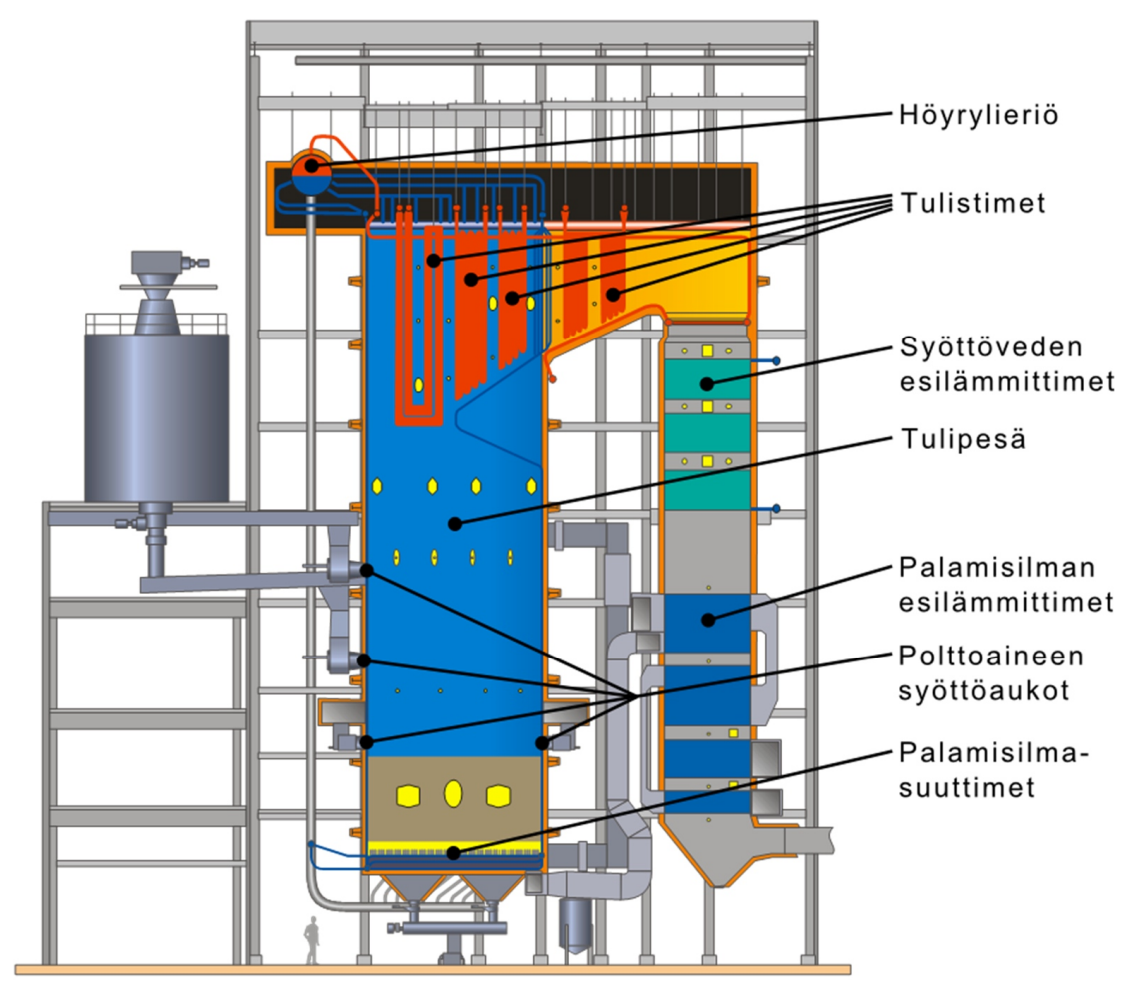

Kuva 1. Kerrosleijukattilan ja painerungon pääkomponentit [17].

pahtuman lämpösäteilystä höyryyn siirtävistä tulistinelementeistä. Tavanomaisen tulistinkammion ja siihen liittyvien aisaputkien rakenne on esitetty kuvassa 3.

Tulistimien hyvin korkeista $500-600{ }^{\circ} \mathrm{C}$ :een käyttölämpötiloista johtuen niissä joudutaan käyttämään kalliita ja hyvin runsaasti seostettuja kuumalujia ja hitaasti viruvia painelaiteteräslaatuja. Koska tulistimesta vain tulistinelementit ovat kosketuksissa kuumien savukaasujen kanssa ja koska vain tulistinelementit altistuvat tulipesässä tapahtuvasta palamisesta aiheutuvalle lämpösäteilylle ja savukaasujen aiheuttamalle korroosiolle, valmistetaan tulistinelementit yleensä eri putkimateriaalista kuin tulistimen aisaputket sen tuottamien kustannussäästöjen vuoksi. Tulistin altistuu käyttöikänsä aikana sekä voimalaitoksen kylmäkäynnistysten aiheuttamalle väsyttävälle kuormitukselle että tulistimen hyvin korkean toimintalämpötilan aiheuttamalle virumiselle, joiden kummankin aikaansaama yhteisvaikutus vaurioittaa tulistimen osia ja voi aiheuttaa sopimattomalla tulistimen mitoituksella muun muassa putkivuotoja tulistimessa.

\section{Katsaus metallien virumisilmiöön ja virumismalleihin}

\section{Virumisilmiö}

Metallien viruminen on jännityksen alaisena tapahtuvaa ajasta riippuvaa, pysyvää (plastista) muodonmuutosta. Materiaalin mikrotasolla virumismekanismeja ovat dislokaatioden liukuminen ja kiipeäminen, diffuusioviruminen sekä raerajaliukuminen $[9,10,31]$. Virumiskokeissa vetosauvaa kuormitetaan yleensä vakiovoimalla ${ }^{2}$ vakiolämpötilassa mahdol-

\footnotetext{
${ }^{2}$ Materiaalin käyttäytymisen mallintamiseksi vakiojännitystila olisi suotavampi. Vakiojännityksen aikaansaaminen kokeissa on virumisen tertiäärivaiheessa hankalasti toteutettavissa.
} 


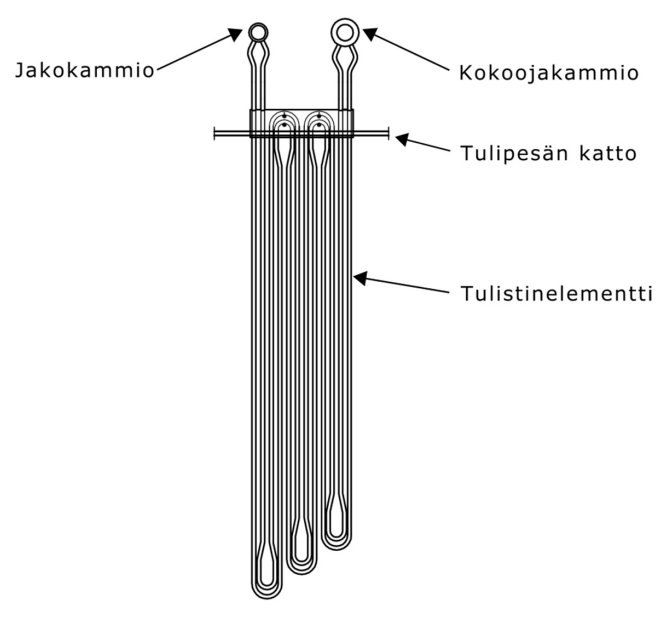

Kuva 2. Tyypillisen riipputulistimen osat ja liitoskohta tulipesän kattoon.

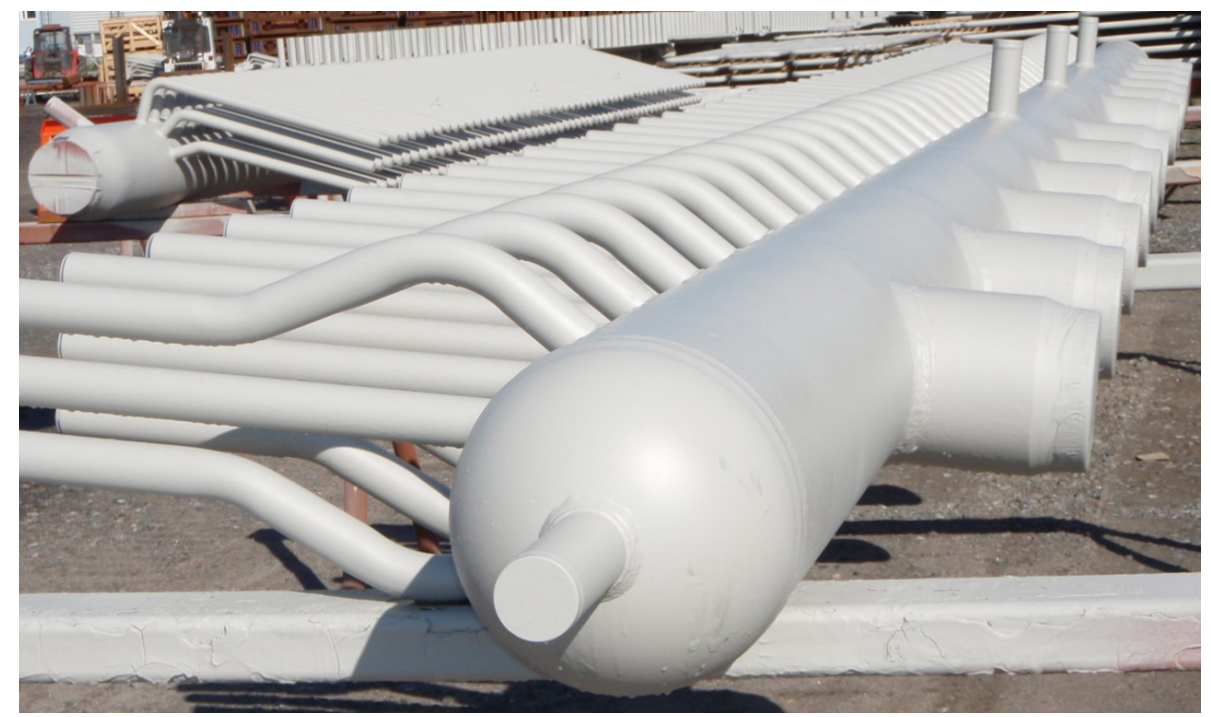

Kuva 3. Tyypillinen iso tulistinkammio ja kammion aisaputket (Valmet Technologies). 


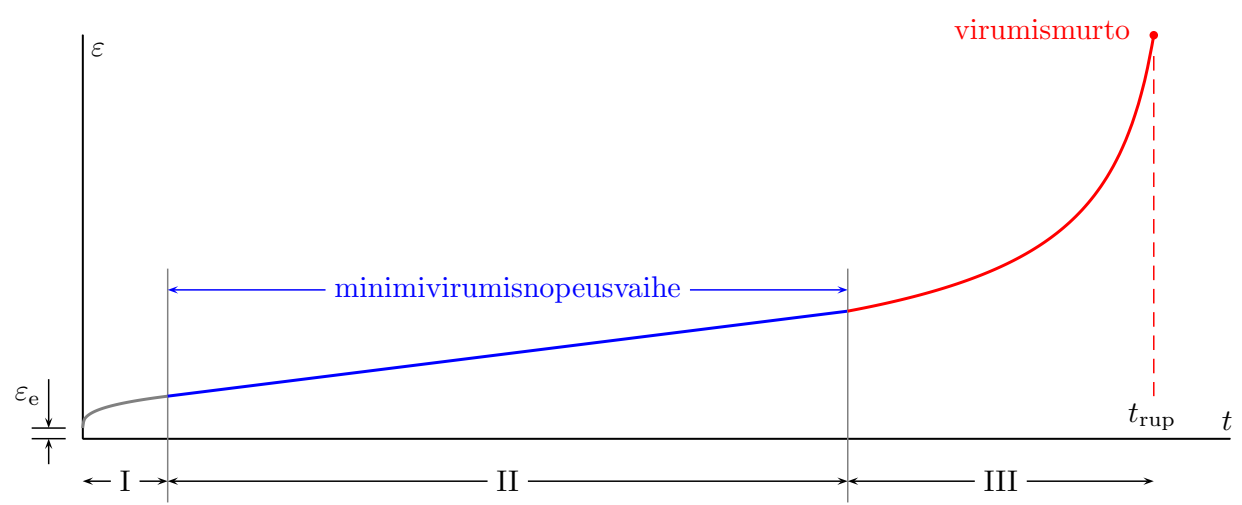

Kuva 4. Tyypillisen vakiovoiman alaisena tehdyn virumiskokeen skemaattinen venymän aikariippuvuus ja virumisvaiheet: I - primääriviruminen, II - sekundääriviruminen, III - tertiääriviruminen.

lisesti murtoon saakka, jolloin tuloksena saadaan virumisvenymä ajan funktiona. Näissä virumiskäyrissä, joissa jännitys on huomattavasti pienempi kuin myötöraja ja lämpötila homologisella ${ }^{3}$ asteikolla välillä 0,3 - 0,5, havaitaan kolme vaihetta kuvan 4 mukaisesti ${ }^{4}$. Näihin vaiheisiin liittyvät virumisvaurion kehitysvaiheet on esitetty kuvassa 4 .

Virumisprosessin primäärivaiheessa virumisnopeus laskee tiettyyn minimiarvoon. Tämä ajanhetki määrää primääriviruma- ja sekundäärivirumavaiheen rajakohdan. Primäärivaiheeseen liittyy materiaalin lujittumista, kun dislokaatioiden liike estyy erkaumapartikkelien vuoksi, ja relaksaatioprosesseja hilavikojen uudelleen järjestymisen seurauksena. Virumisvaurion mallintamisen kannalta voidaan primääriviruminen usein jättää huomiotta, koska vauriota ei tässä vaiheessa vielä synny. Sekundäärivaihetta karakterisoi lähes vakiona pysyvä virumisnopeus, kun kilpailevat lujittumis- ja pehmenemisprosessit, dislokaatioiden syntyminen ja tuhoutuminen, ovat tasapainossa. Raerajoille syntyy tässä vaiheessa yksittäisiä onkaloita. Virumisprosessin kolmannessa vaiheessa eli tertiäärivirumisessa virumisnopeus alkaa jälleen kasvaa, kun raerajoille syntyneet onkalot heikentävät materiaalia. Tähän vaiheeseen voi liittyä myös karbidien ja nitridien muodostusta ja kasvua sekä mikrorakenteen vanhenemista [22]. Onkaloita syntyy ja ne jatkavat kasvua ja kasaantumista ja yhdistymistä synnyttäen raerajoille ensin suuntautuneita kolojonoja, jotka sitten yhdistyvät ensin mikrosäröiksi ja myöhemmin makrosäröiksi. Tämä vaihe päättyy näytteen murtumiseen hetkellä $t_{\text {rup }}$, kuva 4 .

Lämpötilan ja jännityksen vaikutus virumiskäyrään on karkeasti ottaen samanlainen siten, että molempien nostaminen kasvattaa virumisnopeutta ja lyhentää murtoaikaa $t_{\text {rup }}$. Hyvin matalilla jännitystasoilla virumisnopeuden ollessa pieni, viruminen on luonteeltaan diffuusiovirumista. Kun jännitystaso kasvaa, viruminen muuttuu dislokaatiovirumiseksi (viscous glide) [10, 11].

Kuvassa 5 on esitetty metaliseoksille tyypillinen muodonmuutosmekanismikartta, joka kuvaa lämpötilan ja jännityksen vaikutusta virumisprosesseihin [9]. Muodonmuutosmekanismikartassa vakiovirumisnopeuskäyrät on esitetty homologisen lämpötilan ja von Mises-jännityksen funktiona. Kartasta voidaan lukea tiettyä venymänopeutta vastaava, dominoiva virumismekanismi ja vastaava jännitys- ja lämpötilaväli, jolla se odotettavasti

\footnotetext{
${ }^{3}$ Homologisella lämpötila-asteikolla tarkoitetaan aineen sulamislämpöön suhteutettua dimensiotonta lämpötilaa $T_{\mathrm{hom}}=\left(T-T_{\mathrm{m}}\right) / T_{\mathrm{m}}$, jossa $T_{\mathrm{m}}$ on aineen sulamislämpötila absoluuttisella lämpötila-asteikolla.

${ }^{4}$ Virumiskäyttäytymisen kolme vaihetta on raportoitu ensimmäisen kerran da Costa Andraden tutkimuksessa vuodelta 1910 [6].
} 


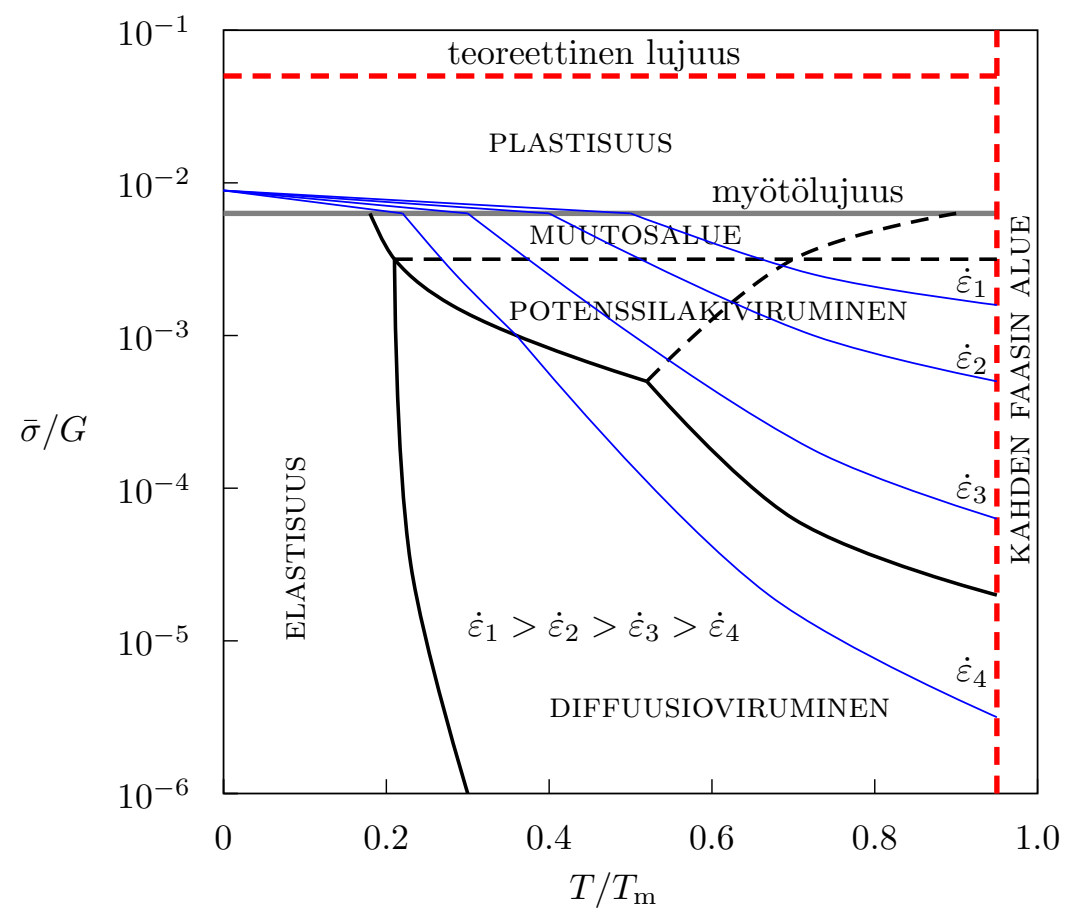

Kuva 5. Metalliseoksen periaatteellinen muodonmuutosmekanismikartta ( $G$ on leikkausmoduuli, $\bar{\sigma}$ von Mises jännitys, $T_{\mathrm{m}}$ sulamislämpötila absoluuttisella lämpötila-asteikolla $T$ ).

esiintyy $[9,11]$. Kuvasta nähdään myös rajakäyrät, jolloin tapahtuu siirtyminen kimmoiselle, plastiselle ja/tai sulamisalueelle.

\section{Klassisia virumismalleja}

Virumismuodonmuutokseen eniten vaikuttavat muuttujat ovat jännitys $\sigma$, aika $t$ ja absoluuttinen lämpötila $T$, joten yleisin mahdollinen jännityksestä, lämpötilasta ja ajasta riippuva malli virumismuodonmuutokselle $\varepsilon_{\mathrm{c}}$ voidaan lausua muodossa [30]

$$
\varepsilon_{\mathrm{c}}=F(\sigma, T, t)
$$

Insinöörisovelluksissa käyttökelpoinen approksimaatio saadaan kun oletetaan virumismuodonmuutos muodossa

$$
\varepsilon_{\mathrm{c}}=f(\sigma) h(T) g(t),
$$

jossa $f(\sigma), h(T)$ ja $g(t)$ ovat jännityksestä $\sigma$, lämpötilasta $T$ ja ajasta $t$ riippuvia funktioita. Yhtälöiden (1) ja (2) mukaisia relaatioita ei valitettavasti voi kirjoittaa eksplisiittisessä muodossa. Virumismallit esitetäänkin yleensä nopeusmuodossa, eli

$$
\dot{\varepsilon}_{\mathrm{c}}=f(\sigma) g^{\prime}(t) h(T) .
$$

Fenomenologisia malleja funktioille $f, g$ ja $h$ on esitetty useita. Useimmin käytetyt primääri- ja sekundäärivirumaa kuvaavat jännitys- ja aikafunktiot on esitetty seuraavassa 
luettelossa [30]:

Norton 1929

$$
\begin{aligned}
f(\sigma) & =C_{1}\left(\sigma / \sigma_{\mathrm{r}}\right)^{p}, \\
f(\sigma) & =C_{2}\left(\exp \left(\sigma / \sigma_{\mathrm{r}}\right)-1\right), \\
f(\sigma) & =C_{3} \exp \left(\sigma / \sigma_{\mathrm{r}}\right), \\
f(\sigma) & =\sinh ^{p}\left(\sigma / \sigma_{\mathrm{r}}\right), \\
g(t) & =\left(1+b t^{1 / 3}\right) \exp (k t)-1, \\
g(t) & =\left(t / t_{\mathrm{c}}\right)^{n}, \quad \text { yleensä } \quad \frac{1}{3} \leq n \leq \frac{1}{2}, \\
g(t) & =C_{1}(1-\exp (-k t))+C_{2} t,
\end{aligned}
$$

joissa $C_{1}, C_{2}, C_{3}, b, p, k, t_{\mathrm{c}}, n$ ja $\sigma_{\mathrm{r}}$ ovat vakioita. Dornin malli antaa hyvän sovituksen koetuloksiin suurilla jännityksen arvoilla, kun taas Nortonin malli on paremmin sopusoinnussa alhaisilla jännityksillä. Garofalon malli toimii yleisesti varsin hyvin sekä pienillä että suurilla jännityksen arvoilla.

Primääriviruman mallinnuksessa ei muotoa (2) olevilla lausekkeilla, joita kutsutaan aikalujittuviksi, saada hyvää vastaavuutta koetuloksiin, mikäli jännitystila on muuttuva $[14,28,30]$. Useita malleja paremman vastaavuuden saamisiksi on esitetty. Näitä malleja ei tässä kuitenkaan selosteta, sillä kattilarakenteiden virumismurron ja virumisväsymisen mallintamisessa ei primäärivirumalla ole suurtakaan merkitystä. Lisäksi nykyisin primääriviruman mallinnus toteutetaan jännitysfunktion $f(\sigma)$ avulla käyttäen joko kinemaattisesti ja/tai isotrooppisesti virumislujittuvia malleja.

Varsin yleisesti lämpötilan vaikutus otetaan huomioon Arrhenius-tyyppisellä funktiolla

$$
h(T) \propto \exp \left(-Q_{\mathrm{c}} / R T\right)
$$

jossa $Q_{\mathrm{c}}$ on aktivaatioenergia ja $R(=8,314 \mathrm{~J} / \mathrm{mol} \mathrm{K})$ on universaali kaasuvakio. Venymänopeuden ja lämpötilan vaikutuksen tuloa

$$
Z=\dot{\varepsilon} \exp \left(Q_{\mathrm{c}} / R T\right)
$$

kutsutaan Zenerin-Hollomonin parametriksi.

Dislokaatioiden kiipeämisen dominoimassa virumassa voidaan sekundääriselle virumanopeudelle johtaa lauseke [10, 31]

$$
\dot{\varepsilon}_{\mathrm{c}}=B \frac{G b}{k T} D_{0} \exp \left(-Q_{\mathrm{c}} / R T\right)\left(\frac{\sigma}{G}\right)^{p},
$$

jossa $G$ on leikkausmoduuli, $k$ Boltzmannin vakio $\left(k=1,38 \cdot 10^{-23} \mathrm{~J} / \mathrm{K}\right), b$ Burgersin vektorin pituus, $D_{0}$ on vakanssidiffuusiokerroin ja $B$ on empiirinen vakio, joka ottaa huomioon muut vaikuttavat tekijät, kuten raekoon vaikutuksen. Potenssille $p$ saadaan arvo 3 tai 4 riippuen yhtälön (13) johdossa käytetystä teoriasta. Mikäli vakanssit diffundoituvat pääsääntöisesti dislokaatioviivoja pitkin, eivätkä häiriintymättömään kidehilaan, saadaan mallista riippuen potenssille $p$ arvot 5 tai 6 . Puhtaille metalleille malli (13) antaakin varsin hyviä tuloksia.

Mikäli lämpötila homologisella asteikolla on alle 0,3 , virumiselle on käytetty logaritmista muotoa olevaa aikafunktiota [10]

$$
\varepsilon_{\mathrm{c}}=\varepsilon_{0} \ln \left(1+t / t_{0}\right),
$$

jolloin virumisprosessin alkunopeus on $\varepsilon_{0} / t_{0}$. 
Metalliseoksilla virumisen jännityseksponentti ei ole vakio, vaan se on lämpötilasta ja jännityksestä riippuva. Kaikilla matala- ja korkeaseosteisilla kuumakestävillä teräksillä riippuvuus vakion $p$ osalta on se, että $p$ pienenee jännityksen pienentyessä. Toisaalta tämä muutos ei ole sileä, vaan siinä esiintyy mekanismin muutos siirryttäessä keskisuurista jännityksistä suuriin. Kuvassa 5 tätä siirtymää edustavat alueet "potenssilakiviruminen" ja "muutosalue".

Myös aktivaatioenergia $Q_{\mathrm{c}}$ riippuu jännityksestä (kasvaen kun jännitys kasvaa) $[3,10]$. Monissa insinöörisovelluksissa suureiden $p$ ja $Q_{\mathrm{c}}$ jännitys- ja lämpötilariippuvuuden luonne voidaan yleensä jättää huomiotta ja käyttää diskreettejä arvoja kaavassa (2). Insinöörisovellusten kannalta tärkeimmät virumisparametrit ovat minimivirumisnopeus ja virumismurtoaika, etenkin niiden riippuvuus lämpötilasta ja jännityksestä.

\section{Virumismallit sisäisten muuttujien avulla}

Klassisten virumisyhtälöiden (4)-(10) sekä (14) sijaan virumista mallinnetaan nykyisin malleilla, joissa käytetään sisäisiä muuttujia ja niiden kehittymistä kuvaavia evoluutioyhtälöitä. Tyypillisesti sisäisten muuttujien $\kappa_{i}$, jotka yleensä ovat skalaareja tai toisen kertaluvun tensoreita, evoluutioyhtälöt ovat muotoa

$$
\dot{\kappa}_{i}=h_{i} \dot{\varepsilon}^{\mathrm{c}}-r_{i}^{\mathrm{dyn}} \kappa_{i} \dot{\varepsilon}^{\mathrm{c}}-r_{i}^{\mathrm{st}} \kappa_{i},
$$

jossa funktiot $h_{i}, r^{\text {dyn }}$ ja $r^{\text {st }}$ kuvaavat myötölujittumista, dynaamista ja staattista toipumista [5].

Laajalle jännitys- ja lämpötila-alueelle soveltuvan virumismallin kehittäminen on monimutkainen tehtävä. Vauriomekaniikkaan perustuva lähestymistapa muodostaa hyvän lähtökohdan, ja sitä on sovellettu useissa tutkimuksissa $[1,4,11,12,13,25,27,34]$. Tässä artikkelissa tarkastellaan etupäässä sekundääristä ja tertiäärivaiheen virumaa, joten yksinkertaisin mahdollinen sisäisten muuttujien joukko koostuu vain yhdestä skalaari-vauriomuuttujasta. Primäärivaiheen viruma voidaan mallintaa käyttäen sisäisenä muuttujana esimerkiksi ekvivalenttia virumisvenymää.

\section{Termodynaaminen formulaatio}

Materiaalimallien johtamisessa, erityisesti kytkettyjen monifysikaalisten ongelmien tapauksessa, tarvitaan kyseisten fysikaalisten ilmiöiden taselakeja, kuten liikemäärän ja liikemäärämomentin taseyhtälöt. Lisäksi vallitsevien prosessien on toteutettava energian säilymislaki eli termodynamiikan ensimmäinen pääsääntö sekä termodynamiikan toinen pääsääntö eli entropiaepäyhtälö. Vallitsevat materiaalin käyttäytymistä kuvaavat yhtälöt voidaan muodostaa termodynaamisesti konsistentilla tavalla käyttäen kahta potentiaalifunktiota. Palautuvien prosessien tilayhtälöt johdataan Helmholtzin ominaisvapaaenergian avulla ja dissipatiivisten prosessien evoluutioyhtälöt vastaavasti dissipaatiopotentiaalista. Tämä takaa sen, että sopivilla potentiaalifunktioiden valinnalla entropiaepäyhtälö eli Clausiuksen-Duhemin epäyhtälö voidaan toteuttaa kaikille termodynaamisesti luvallisille prosesseille [8, 24, 29, 32].

\section{Energiatasapaino}

Termodynamiikan ensimmäinen pääsääntö eli energiatasapaino voidaan kirjoittaa muodossa

$$
\frac{\mathrm{d}}{\mathrm{d} t}(\mathcal{E}+\mathcal{K})=\mathcal{P}_{\text {mech }}+\mathcal{P}_{\text {heat }}
$$


jossa $\mathcal{E}$ ja $\mathcal{K}$ ovat sisä- ja kineettinen energia, jotka määritellään yhtälöillä

$$
\begin{aligned}
\mathcal{E} & =\int_{V} \rho e \mathrm{~d} V \\
\mathcal{K} & =\frac{1}{2} \int_{V} \rho \boldsymbol{v} \cdot \boldsymbol{v} \mathrm{d} V,
\end{aligned}
$$

jossa $e$ on ominaissisäenergia, joka on ominaisentropiasta $s$, muodonmuutoksesta $\varepsilon$, sisäisestä muuttujasta $\kappa$ ja eheydestä $\omega$ riippuva tilafunktio ja $\boldsymbol{v}$ on siirtymänopeus. Ulkoisten voimien mekaaninen teho määritellään lausekkeella

$$
\mathcal{P}_{\text {mech }}=\int_{V} \rho \boldsymbol{b} \cdot \boldsymbol{v} \mathrm{d} V+\int_{S} \boldsymbol{t} \cdot \boldsymbol{v} \mathrm{d} S
$$

ja vastaavasti ei-mekaaninen teho, joka tässä otaksutaan vain termisten prosessien tehona, on muotoa

$$
\mathcal{P}_{\text {heat }}=\int_{V} \rho \mathcal{R}_{\text {heat }} \mathrm{d} V-\int_{S} \boldsymbol{q} \cdot \boldsymbol{n} \mathrm{d} S
$$

jossa $\mathcal{R}_{\text {heat }}$ on lämmöntuottonopeus massaa kohden ja $\boldsymbol{q}$ lämpövuovektori. Muutamien välivaiheiden jälkeen energiataseen lausekkeeksi saadaan

$$
\int_{V} \rho \dot{e} \mathrm{~d} V=\int_{V}\left(\boldsymbol{\sigma}: \operatorname{grad} \boldsymbol{v}+\rho \mathcal{R}_{\text {heat }}-\operatorname{div} \boldsymbol{q}\right) \mathrm{d} V,
$$

jossa : merkitsee toisen kertaluvun tensoreiden kaksoispistetuloa, eli $\boldsymbol{A}: \boldsymbol{B}=\operatorname{tr}\left(\boldsymbol{A}^{\mathrm{T}} \boldsymbol{B}\right)$. Määrittelemällä muodonmuutostensori

$$
\boldsymbol{\varepsilon}=\frac{1}{2}\left[\operatorname{grad} \boldsymbol{u}+(\operatorname{grad} \boldsymbol{u})^{\mathrm{T}}\right],
$$

voidaan energiataseen lauseke (21) kirjoittaa paikallisessa muodossa

$$
\rho \dot{e}=\boldsymbol{\sigma}: \dot{\varepsilon}+\rho \mathcal{R}_{\text {heat }}-\operatorname{div} \boldsymbol{q} .
$$

Ominaissisäenergia $e$ on ominaisentropian $s$, muodonmuutoksen $\varepsilon$, sisäisen muuttujan $\kappa$ ja eheyden $\omega$ funktio. Käyttämällä osittaista Legendren muunnosta, saadaan Helmholtzin ominaisvapaaenergia $\psi=e-s T$. Tällöin ominaissisäenergian tilasuureena oleva ominaisentropia korvautuu Helmholtzin ominaisvapaaenergian lausekkeessa absoluuttisella lämpötilalla $T$, joka on mitattavissa oleva suure. Tällöin paikallinen energiayhtälö (23) saadaan muotoon

$$
\rho(\dot{\psi}+\dot{s} T+s \dot{T})=\boldsymbol{\sigma}: \dot{\varepsilon}+\rho \mathcal{R}_{\text {heat }}-\operatorname{div} \boldsymbol{q} .
$$

Palataan energiayhtälön muokkaamiseen tarkastelemalla ensin termodynamiikan toista pääsääntöä.

\section{Entropiaepäyhtälö}

Termodynamiikan toinen pääsääntö asettaa rajoitteita mahdollisille prosesseille. Määritellään entropia $S=\int \rho s \mathrm{~d} V$, jossa $s$ on ominaisentropia. Entropiaepäyhtälö eli ClausiuksenDuhemin epäyhtälö on

$$
\frac{\mathrm{d}}{\mathrm{d} t} \int_{V} \rho s \mathrm{~d} V \geq \int_{V} \frac{\rho \mathcal{R}_{\text {heat }}}{T} \mathrm{~d} V-\int_{S} \frac{\boldsymbol{q} \cdot \boldsymbol{n}}{T} \mathrm{~d} S
$$


joka kertoo sen, että termomekaanisen systeemin kokonaisentropian kasvunopeuden on oltava suurempi tai yhtäsuuri kuin systeemin lämmönlähteistä ja siihen kohdistuvasta lämpövuosta muodostuva entropiantuotto.

Muutamien välivaiheiden jälkeen saadaan systeemin dissipaatiotehon lausekkeeksi

$$
\gamma=-\rho(\dot{\psi}+s \dot{T})+\boldsymbol{\sigma}: \dot{\varepsilon}-T^{-1} \operatorname{grad} T \cdot \boldsymbol{q}
$$

ja entropiaepäyhtälö voidaan kirjoittaa yksinkertaisesti

$$
\gamma \geq 0
$$

Rajoittumalla geometrisesti lineaariseen malliin, muodonmuutostensori $\varepsilon$ voidaan jakaa summamuodossa elastiseen $\varepsilon_{\mathrm{e}}$, epäelastiseen virumaa kuvaavaan osaan $\varepsilon_{\mathrm{c}}$ sekä lämpövenymään $\varepsilon_{\mathrm{th}}$

$$
\varepsilon=\varepsilon_{\mathrm{e}}+\varepsilon_{\mathrm{c}}+\varepsilon_{\mathrm{th}}
$$

Helmholtzin ominaisvapaaenergia $\psi$ on lämpötilan $T$, vauriota kuvaavan eheyden $\omega$, termoelastisen muodonmuutoksen $\varepsilon_{\mathrm{te}}=\varepsilon-\varepsilon_{\mathrm{c}}$ ja sisäisen muuttujan $\kappa$ funktio, eli $\psi=$ $\psi\left(T, \varepsilon_{\mathrm{te}}, \omega, \kappa\right)$, joten dissipaatiotehon lauseke muuntuu muotoon

$$
\gamma=-\rho\left(s+\frac{\partial \psi}{\partial T}\right) \dot{T}+\left(\boldsymbol{\sigma}-\rho \frac{\partial \psi}{\partial \varepsilon_{\mathrm{te}}}\right): \dot{\varepsilon}_{\mathrm{te}}+\boldsymbol{\sigma}: \dot{\varepsilon}_{\mathrm{c}}-\rho \frac{\partial \psi}{\partial \omega} \dot{\omega}-\rho \frac{\partial \psi}{\partial \kappa} \dot{\kappa}-T^{-1} \operatorname{grad} T \cdot \boldsymbol{q} .
$$

Eheysmuuttujan $\omega$ ja vauriomuuttujan $D$ välinen relaatio on

$$
D=1-\omega
$$

Eheysmuuttujalla on arvo 1 vaurioitumattomassa alkutilassa ja arvo 0 täysin vaurioituneessa tilassa. Vastaavat arvot ovat päinvastaiset vauriomuuttujan tapauksessa. Eheysmuuttujan käyttö on perusteltavissa lausekkeiden yksinkertaistumisen vuoksi.

Systeemin dissipatiiviset mekanismit kuvataan dissipaatiopotentiaalin, tai tässä oikeammin komplementaarisen dissipaatiopotentiaalin $\varphi=\varphi(Y, K, \boldsymbol{q}, \boldsymbol{\sigma} ; T)$ avulla, joka on argumenttien $Y, K, \boldsymbol{q}$ ja $\boldsymbol{\sigma}$ suhteen monotoninen funktio. Dissipaatioteho $\gamma$ määritellään

$$
\gamma=\frac{\partial \varphi}{\partial \boldsymbol{q}} \cdot \boldsymbol{q}+\frac{\partial \varphi}{\partial \boldsymbol{\sigma}}: \boldsymbol{\sigma}+\frac{\partial \varphi}{\partial K} K+\frac{\partial \varphi}{\partial Y} Y
$$

Määrittelemällä termodynaamiset voimat $Y=\rho \partial \psi / \partial \omega$ ja $K=\rho \partial \psi / \partial \kappa$, sekä asettamalla dissipaatiotehon lauseke (29) yhtäsuureksi määritelmän (31) kanssa, saadaan yhtälö

$$
\begin{aligned}
-\rho\left(s+\frac{\partial \psi}{\partial T}\right) \dot{T} & +\left(\boldsymbol{\sigma}-\rho \frac{\partial \psi}{\partial \varepsilon_{\mathrm{te}}}\right): \dot{\varepsilon}_{\mathrm{te}}+\left(\dot{\varepsilon}_{\mathrm{c}}-\frac{\partial \varphi}{\partial \boldsymbol{\sigma}}\right): \boldsymbol{\sigma} \\
& -\left(\dot{\omega}+\frac{\partial \varphi}{\partial Y}\right) Y-\left(\dot{\kappa}+\frac{\partial \varphi}{\partial K}\right) K-\left(T^{-1} \operatorname{grad} T+\frac{\partial \varphi}{\partial \boldsymbol{q}}\right) \cdot \boldsymbol{q}=0
\end{aligned}
$$

Koska yhtälön on toteuduttava kaikilla mahdollisilla termodynaamisesti luvallisilla pro- 
sesseilla $\dot{T}, \dot{\varepsilon}_{\text {te }}, \boldsymbol{\sigma}, Y, K$ ja $\boldsymbol{q}$, saadaan seuraavat yleiset konstitutiiviset yhtälöt

$$
\begin{aligned}
s & =-\frac{\partial \psi}{\partial T}, \\
\boldsymbol{\sigma} & =\rho \frac{\partial \psi}{\partial \boldsymbol{\varepsilon}_{\mathrm{te}}}, \\
\dot{\boldsymbol{\varepsilon}}_{\mathrm{c}} & =\frac{\partial \varphi}{\partial \boldsymbol{\sigma}}, \\
\dot{\omega} & =-\frac{\partial \varphi}{\partial Y}, \\
\dot{\kappa} & =-\frac{\partial \varphi}{\partial K}, \\
T^{-1} \operatorname{grad} T & =-\frac{\partial \varphi}{\partial \boldsymbol{q}} .
\end{aligned}
$$

Sijoittamalla nämä yleiset konstitutiiviset yhtälöt energiayhtälön paikalliseen muotoon (24), saadaan

$c_{\varepsilon} \dot{T}=-\operatorname{div} \boldsymbol{q}+\rho \mathcal{R}_{\text {heat }}+\boldsymbol{\sigma}: \dot{\varepsilon}_{\mathrm{c}}+\rho T \frac{\partial^{2} \psi}{\partial \varepsilon_{\mathrm{te}} \partial T}: \dot{\varepsilon}_{\mathrm{te}}+\left(\rho T \frac{\partial^{2} \psi}{\partial \omega \partial T}-Y\right) \dot{\omega}+\left(\rho T \frac{\partial^{2} \psi}{\partial \kappa \partial T}-K\right) \dot{\kappa}$,

jossa lämpökapasiteetti $c_{\varepsilon}$ määritellään

$$
c_{\varepsilon}=-\rho T \frac{\partial^{2} \psi}{\partial T^{2}} .
$$

Yhtälö (39) on termomekaanisesti kytketty lämpöyhtälö, jossa mekaanisen systeemin aiheuttama lämpöenergian tuotto näkyy yhtälön oikean puolen kolmessa viimeisessä termissä, jotka kuvaavat viskoplastisuuden, termoelastisuuden ja vaurion aiheuttamaa lämmöntuottoa. Näiden termien merkitystä tarkastellaan myöhemmin sivulla 439.

Mikäli dissipaatiofunktio on konveksi kaikkien termodynaamisten voimien suhteen, toteutuu Clausiuksen-Duhemin epäyhtälö (27) automaattisesti. Konveksisuus ei kuitenkaan ole välttämätön ehto. Riittävä ehto dissipaatioepäyhtälön toteutumiselle on dissipaatiopotentiaalin monotonisuus argumenttiensa suhteen. ${ }^{5}$ Tässä artikkelissa tarkasteltavat mallit perustuvat konveksiin dissipaatiopotentiaaliin, joten dissipaatioepäyhtälö toteutuu kaikille termodynaamisesti luvallisille prosesseille.

\section{Tarkasteltavat mallit}

Helmholtzin ominaisvapaaenergia on neljän tilamuuttujan, eli absoluuttisen lämpötilan $T$, termoelastisten muodonmuutosten $\varepsilon_{\text {te }}$ sekä eheyden $\omega$ ja plastista lujittumista kuvaavan muuttujan $\kappa$, funktio

$$
\psi=\psi\left(T, \varepsilon_{\mathrm{te}}, \omega, \kappa\right) .
$$

Mikäli vaurioitumista ja plastista käyttäytymistä kuvaavat muuttujat $\omega$ ja $\kappa$ ovat vakioita, Helmholtzin ominaisvapaaenergian avulla saadaan palautuvan käyttäytymisen tilayhtälöt. Rajoittamalla kimmoinen käyttäytyminen lineaariseksi, voidaan Helmholtzin ominasvapaaenergialle valitaan lauseke

$$
\rho \psi\left(T, \varepsilon_{\mathrm{te}}, \omega, \kappa\right)=\rho c_{\varepsilon}\left(T-T \ln \frac{T}{T_{\mathrm{r}}}\right)+\frac{1}{2}\left(\varepsilon_{\mathrm{te}}-\varepsilon_{\mathrm{th}}\right): \omega \boldsymbol{C}_{\mathrm{e}}:\left(\varepsilon_{\mathrm{te}}-\varepsilon_{\mathrm{th}}\right)+\rho \psi_{\mathrm{p}}(\kappa, T),
$$

\footnotetext{
${ }^{5}$ Monotonisuusvaatimus on testattava origon kummallakin puolella erikseen.
} 
jossa $\boldsymbol{C}_{\mathrm{e}}$ on materiaalin kimmotensori, $\boldsymbol{\alpha}$ lämpöpitenemistensori, $T_{\mathrm{r}}$ viitelämpötila ja $\varepsilon_{\mathrm{th}}=\boldsymbol{\alpha}\left(T-T_{\mathrm{r}}\right)$ lämpövenymä. Isotrooppisessa aineessa kimmotensori ja lämpöpitenemistensori ovat muotoa

$$
\boldsymbol{C}_{\mathrm{e}}=\lambda \boldsymbol{I} \otimes \boldsymbol{I}+2 \mu \mathcal{I}, \quad \text { ja } \quad \boldsymbol{\alpha}=\alpha \boldsymbol{I},
$$

jossa $\lambda$ ja $\mu$ ovat Lamén vakioita, $\alpha$ pituuden lämpötilakerroin, $\boldsymbol{I}$ toisen kertaluvun identiteettitensori ja $\mathcal{I}$ on neljännen kertaluvun identiteettitensori, joka on muotoa $\mathcal{I}_{i j k l}=$ $\frac{1}{2}\left(\delta_{i k} \delta_{j l}+\delta_{i l} \delta_{j k}\right)$. Lamén vakiot lausuttuna kimmokertoimen $E$ ja Poissonin luvun $\nu$ avulla ovat

$$
\lambda=\frac{\nu E}{(1+\nu)(1-2 \nu)}, \quad \mu=\frac{E}{2(1+\nu)},
$$

jossa $E$ ja $\nu$ voivat olla lämpötilan funktioita. Plastista lujittumista kuvaavan sisäisen muuttujan määrittelemälle osalle valitaan muoto

$$
\rho \psi_{\mathrm{p}}(\kappa)=K_{\infty}\left[\kappa+\frac{K_{\infty}}{h} \exp \left(-h \kappa / K_{\infty}\right)\right]
$$

jossa materiaaliparametrit $h$ ja $K_{\infty}$ riippuvat lämpötilasta.

Dissipaatiopotentiaali voidaan jakaa termiseen, vaurioituvaan ja viskoplastiseen osaan seuraavasti

$$
\varphi(Y, K, \boldsymbol{q}, \boldsymbol{\sigma} ; T, \omega)=\varphi_{\mathrm{th}}(\boldsymbol{q} ; T)+\varphi_{\mathrm{d}}(Y ; T, \omega)+\varphi_{\mathrm{c}}(\boldsymbol{\sigma}, K ; T, \omega),
$$

jossa termisen osan potentiaalifunktio on muotoa

$$
\varphi_{\mathrm{th}}(\boldsymbol{q} ; T)=\frac{1}{2} T^{-1} \boldsymbol{q} \cdot \boldsymbol{k}^{-1} \cdot \boldsymbol{q},
$$

ja $\boldsymbol{k}$ on lämmönjohtavuustensori, joka isotrooppisen lämmönjohtavuuden tapauksessa on yksinkertaisesti $\boldsymbol{k}=k \boldsymbol{I}$. Lämmönjohtavuus $k$ voi riippua lämpötilasta ${ }^{6}$. Tässä artikkelissa esitetään virumisvaurion mallintamiseen kaksi mallia, joista parametrien suhteen monimuotoisempi kuvataan potentiaaleilla

$$
\begin{aligned}
\varphi_{\mathrm{d}}(Y ; T, \omega) & =\frac{h_{\mathrm{d}}(T)}{r+1} \frac{Y_{\mathrm{r}}}{t_{\mathrm{d}} \omega^{k}}\left(\frac{Y}{Y_{\mathrm{r}}}\right)^{r+1}, \\
\varphi_{\mathrm{c}}(\boldsymbol{\sigma} ; T, \omega) & =\frac{h_{\mathrm{c}}(T)}{p+1} \frac{\omega \sigma_{\mathrm{rc}}}{t_{\mathrm{c}}}\left(\frac{\bar{\sigma}}{\omega \sigma_{\mathrm{rc}}}\right)^{p+1},
\end{aligned}
$$

jossa $Y_{\mathrm{r}}$ on termodynaamisen voiman $Y$ vapaasti valittava viitearvo ja $\bar{\sigma}=\sqrt{3 J_{2}}$ on von Misesin tehollinen jännitys. Yllä $t_{\mathrm{c}}$ on virumisprosessin karakteristinen aika, joka on verrannollinen relaksaatioaikaan, ja $h_{\mathrm{c}}, h_{\mathrm{d}}$ Arrhenius-tyyppisiä termisiä aktivaatiofunktioita $h_{i}(T)=\exp \left(-Q_{i} / R T\right)$, jossa $Q_{\mathrm{c}}$ ja $Q_{\mathrm{d}}$ ovat virumis- ja vaurioprosessien aktivaatioenergioita ja $R$ yleinen kaasuvakio. Virumismallin viitejännitys $\sigma_{\mathrm{rc}}$ on vapaasti valittavissa, valitaan se tässä myötöjännityksen arvoksi $\sigma_{\mathrm{rc}}=\sigma_{\mathrm{y}}(\kappa, T)=\sigma_{\mathrm{y} 0}(T)+K(\kappa, T)$. Valinnalla (45) myötöjännitykseksi saadaan

$$
\sigma_{\mathrm{y}}=\sigma_{\mathrm{y} 0}(T)+K_{\infty}\left(1-\exp \left(-h \kappa / K_{\infty}\right)\right) .
$$

${ }^{6}$ Vaurioituminen vaikuttaa myös lämmönjohtavuuteen, joten se voi olla myös eheysmuuttujan funktio. Vaurioituminen johtaa usein johtavuusominaisuuksien anisotropiaan. Tässä artikkelissa lämmönjohtavuuden riippuvuutta vauriomuuttujasta ei kuitenkaan käsitellä. 
Potentiaalifunktio (45) kuvaa siten plastista materiaalia, jolla on maksimilujuus $\sigma_{\mathrm{f}}=$ $\sigma_{\mathrm{y} 0}+K_{\infty}$, eli täten $K_{\infty}=\sigma_{\mathrm{f}}-\sigma_{\mathrm{y} 0}$. Virumismalli on Nortonin mallin tyyppiä, ja vauriopotentiaali Kachanov-Rabotnov-mallin mukainen $[15,16]$.

Dissipaatiopotentiaalit (47), (48) ja (49) ovat muuttujiensa suhteen konvekseja funktioita, mikäli lämmönjohtavuustensori on positiivisesti definiitti ja parametrit $r$ sekä $p$ toteuttavat $r, p \geq 1$.

Yleisistä konstitutiivisista yhtälöistä (33)-(38) saadaan nyt yhtälöt ${ }^{7}$

$$
\begin{aligned}
\boldsymbol{\sigma} & =\omega \boldsymbol{C}_{\mathrm{e}}: \boldsymbol{\varepsilon}_{\mathrm{e}} \\
\dot{\boldsymbol{\varepsilon}}_{\mathrm{c}} & =\frac{h_{\mathrm{c}}}{t_{\mathrm{c}}}\left(\frac{\bar{\sigma}}{\omega \sigma_{\mathrm{rc}}}\right)^{p} \frac{\partial \bar{\sigma}}{\partial \boldsymbol{\sigma}}, \\
\dot{\omega} & =-\frac{h_{\mathrm{d}}}{t_{\mathrm{d}} \omega^{k}}\left(\frac{Y}{Y_{\mathrm{r}}}\right)^{r}, \\
\dot{\kappa} & =\frac{p}{p+1} \frac{\omega h_{\mathrm{c}}}{t_{\mathrm{c}}}\left(\frac{\bar{\sigma}}{\omega \sigma_{\mathrm{rc}}}\right)^{p+1}, \\
\boldsymbol{q} & =-\boldsymbol{k} \operatorname{grad} T .
\end{aligned}
$$

Termodynaamiselle voimalle $Y$ saadaan

$$
Y=\rho \frac{\partial \psi}{\partial \omega}=\frac{1}{2} \varepsilon_{\mathrm{e}}: \boldsymbol{C}_{\mathrm{e}}: \boldsymbol{\varepsilon}_{\mathrm{e}}=\frac{1}{2 \omega^{2}} \boldsymbol{\sigma}: \boldsymbol{C}_{\mathrm{e}}^{-1}: \boldsymbol{\sigma} .
$$

Isotrooppisen aineen tapauksessa voidaan termodynaaminen voima $Y$ saattaa muotoon

$$
Y=\frac{1}{\omega^{2}}\left[\frac{(1+\nu)}{3 E} \bar{\sigma}^{2}+\frac{3(1-2 \nu)}{2 E} \sigma_{\mathrm{m}}^{2}\right],
$$

jossa $\bar{\sigma}=\sqrt{3 J_{2}}$ von Misesin tehollinen jännitys, ja $\sigma_{\mathrm{m}}=\frac{1}{3} \operatorname{tr} \boldsymbol{\sigma}$ on hydrostaattinen jännitys. Termodynaaminen voima voidaan myös kirjoittaa muodossa

$$
Y=\frac{\bar{\sigma}^{2}}{2 E \omega^{2}}\left[\frac{2}{3}(1+\nu)+3(1-2 \nu)\left(\frac{\sigma_{\mathrm{m}}}{\bar{\sigma}}\right)^{2}\right]=\frac{\bar{\sigma}^{2}}{2 E \omega^{2}} R_{\nu},
$$

jossa $\sigma_{\mathrm{m}} / \bar{\sigma}$ on jännityksen kolmiaksiaalisuussuhde, joka on hyvin merkittävässä asemassa materiaalin murtumisessa. Materiaalin sitkeys pienenee kolmiaksiaalisuussuhteen kasvaessa. Dimensiotonta termiä $R_{\nu}$ kutsutaan kolmiaksiaalisuusfunktioksi [23]. Mikäli termodynaamisen voiman viitearvoksi $Y_{\mathrm{r}}$ valitaan

$$
Y_{\mathrm{r}}=\frac{\sigma_{\mathrm{rd}}^{2}}{2 E}
$$

saadaan vauriota ajavalle termodynaamiselle voimasuureelle $Y / Y_{\mathrm{r}}$ lauseke

$$
\frac{Y}{Y_{\mathrm{r}}}=\frac{1}{\omega^{2}}\left[\frac{2(1+\nu)}{3}\left(\frac{\bar{\sigma}}{\sigma_{\mathrm{rd}}}\right)^{2}+3(1-2 \nu)\left(\frac{\sigma_{\mathrm{m}}}{\sigma_{\mathrm{rd}}}\right)^{2}\right] .
$$

Korkeissa lämpötiloissa tehtävää virumiskoetta varten on tarkoituksenmukaista valita $\sigma_{\mathrm{rd}}=\sigma_{\mathrm{rc}}=\sigma_{\mathrm{y} 0}$. Lämpötilan laskiessa virumisen vaikutus vaurionkehitykseen pienenee. Tätä voitaisiin mallintaa käyttämällä valintaa

$$
\sigma_{\mathrm{rd}}=\sigma_{\mathrm{y} 0}+\frac{1}{2}\left(\sigma_{\mathrm{f}}-\sigma_{\mathrm{y} 0}\right)\left[1-\tanh \left(\frac{T-T_{\mathrm{tr}}}{\Delta T}\right)\right] .
$$

${ }^{7}$ Venymä $\varepsilon_{\mathrm{e}}$ pitää sisällään myös vaurion, joten sitä voitaisiin kutsua vaurioelastiseksi venymäksi: $\varepsilon_{\mathrm{e}}=\omega^{-1} \boldsymbol{C}_{\mathrm{e}}^{-1} \boldsymbol{\sigma}$. 
Tällä valinnalla vaurion viitejännitys $\sigma_{\mathrm{rd}}$ on alhaisissa lämpötiloissa murtojännityksen $\sigma_{\mathrm{f}}$ suuruinen ja laskee myötöjännityksen arvoon $\sigma_{\mathrm{y} 0}$ transitiolämpötilan $T_{\mathrm{tr}}$ ympäristössä lämpötilavälillä $\left(T_{\mathrm{tr}}-\Delta T, T_{\mathrm{tr}}+\Delta T\right)$.

Sisäisen muuttujan $\kappa$ ja tehollisen virumisvenymän $\bar{\varepsilon}_{\mathrm{c}}$ nopeuksille saadaan relaatio

$$
\dot{\kappa}=\frac{p}{p+1} \omega\left(\frac{\bar{\sigma}}{\omega \sigma_{\mathrm{rc}}}\right) \dot{\bar{\varepsilon}}_{\mathrm{c}}
$$

jossa tehollinen virumisvenymänopeus on

$$
\dot{\bar{\varepsilon}}_{\mathrm{c}}=\sqrt{\frac{2}{3} \dot{\varepsilon}_{\mathrm{c}}: \dot{\varepsilon}_{\mathrm{c}}}
$$

\section{Virumiskoe}

Virumiskokeista tehtävää materiaaliparametrien määritystä varten kirjoitetaan materiaalimalli yksiulotteisessa tapauksessa, jolloin se tietyissä kuormitustilanteissa kuten vakiolämpötilan ja vakiojännityksen alaisessa virumiskokeessa voidaan integroida suljetussa muodossa. Jännityksen ja muodonmuutoksen välinen yhteys on nyt

$$
\sigma=\omega E\left(\varepsilon-\varepsilon_{\mathrm{th}}-\varepsilon_{\mathrm{c}}\right),
$$

ja virumisvenymänopeudelle saadaan

$$
\dot{\varepsilon}_{\mathrm{c}}=\frac{h_{\mathrm{c}}(T)}{t_{\mathrm{c}}}\left(\frac{\sigma}{\omega \sigma_{\mathrm{rc}}}\right)^{p},
$$

jossa $t_{\mathrm{c}}$ on relaksaatioaikaan verrannollinen karakteristinen aika, $h_{\mathrm{c}}$ Arrhenius-tyyppinen terminen aktivaatiofunktio, $h_{\mathrm{c}}(T)=\exp \left(-Q_{\mathrm{c}} / R T\right)$, jossa $Q_{\mathrm{c}}$ on aktivaatioenergia ja $R$ yleinen kaasuvakio. Vapaasti valittavan viitejännityksen $\sigma_{\mathrm{rc}}$ arvoksi valitaan myötöjännitys $\sigma_{\mathrm{r}}=\sigma_{\mathrm{y} 0}(T)$. Koska testi tehdään vakiolämpötilassa, voidaan lämpövenymän osuus jättää huomioon ottamatta.

Relaksaatioajalla tarkoitetaan aikaa, jossa mallin mukainen jännitysten täydellinen relaksaatio tapahtuu, mikäli relaksaatio tapahtuisi alkunopeudella. Tätä on havainnollistettu kuvassa 6. Tässä työssä käytetyn Nortonin mallin relaksaatioajalle $t_{\text {rel }}$ voidaan johtaa kaava

$$
t_{\mathrm{rel}}=\frac{\sigma_{\mathrm{rc}} t_{\mathrm{c}}}{E h_{\mathrm{c}}}=\frac{\varepsilon_{\mathrm{r}} t_{\mathrm{c}}}{h_{\mathrm{c}}},
$$

jossa $\varepsilon_{\mathrm{r}}=\sigma_{\mathrm{rc}} / E$. Relaksaatioaika riippuu siten lämpötilasta suureiden $\sigma_{\mathrm{rc}}, E$ ja $h_{\mathrm{c}}$ lämpötilariippuvuden johdosta.

\section{Malli 1}

Vaurionkehitystä kuvaava Kachanov-Rabotnov tyyppinen malli (53) on siis

$$
\dot{\omega}=-\frac{h_{\mathrm{d}}(T)}{t_{\mathrm{d}} \omega^{k}}\left(\frac{Y}{Y_{\mathrm{r}}}\right)^{r},
$$

jossa

$$
Y=\frac{\sigma^{2}}{2 \omega^{2} E}
$$




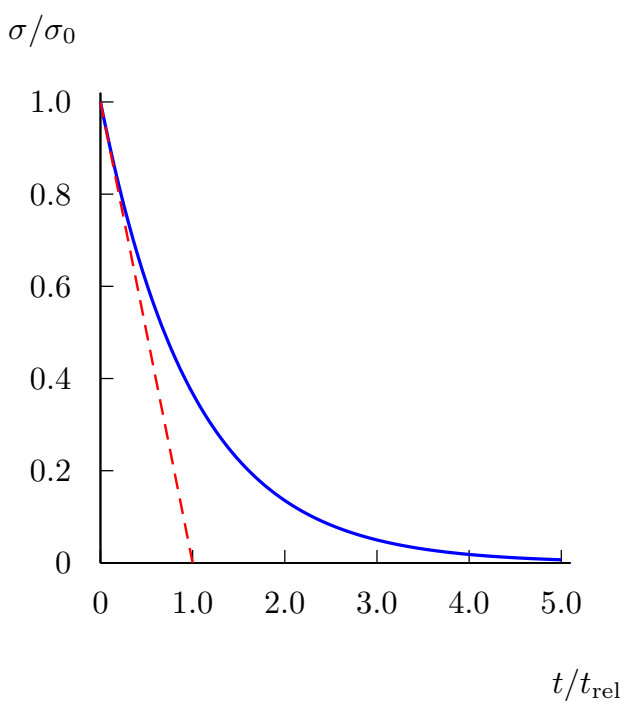

Kuva 6. Relaksaatioajan käsite ( $\sigma_{0}$ on jokin jännitysarvo).

ja $h_{\mathrm{d}}(T)=\exp \left(-Q_{\mathrm{d}} / R T\right)$. Tällöin saadaan vaurionkehityksen evoluutioyhtälöksi

$$
\dot{\omega}=-\frac{h_{\mathrm{d}}(T)}{t_{\mathrm{d}} \omega^{k+2 r}}\left(\frac{|\sigma|}{\sigma_{\mathrm{rd}}}\right)^{2 r} .
$$

Viitejännityksen arvoksi valitaan lujittumaton myötöjännitys $\sigma_{\mathrm{rd}}=\sigma_{\mathrm{rc}}=\sigma_{\mathrm{y} 0} \equiv \sigma_{\mathrm{r}}$. Vetokokeessa jännitys on positiivinen joten itseisarvon merkit voi jättää merkitsemättä. Integroimalla evoluutioyhtälö (68) saadaan eheyden aikariippuvuudeksi

$$
\omega=\left[1-(1+k+2 r) h_{\mathrm{d}}\left(\frac{\sigma}{\sigma_{\mathrm{r}}}\right)^{2 r} \frac{t}{t_{\mathrm{d}}}\right]^{1 /(1+k+2 r)} .
$$

Virumismurtoajaksi $(\omega=0)$ saadaan lauseke

$$
t_{\text {rup }}=\frac{1}{(1+k+2 r) h_{\mathrm{d}}}\left(\frac{\sigma}{\sigma_{\mathrm{r}}}\right)^{-2 r} t_{\mathrm{d}}
$$

Tämä voidaan kirjoittaa myös muodossa

$$
\frac{\sigma}{\sigma_{\mathrm{r}}}=\left((1+k+2 r) h_{\mathrm{d}} \frac{t_{\mathrm{rup}}}{t_{\mathrm{d}}}\right)^{-1 / 2 r}
$$

Integroimalla konstitutivinen yhtälö (65) saadaan vakiojännityksen alaisen virumiskokeen virumisvenymän lausekkeeksi

$$
\varepsilon_{\mathrm{c}}=\frac{1}{1+k+2 r-p} \cdot \frac{t_{\mathrm{d}} h_{\mathrm{c}}}{t_{\mathrm{c}} h_{\mathrm{d}}}\left(\frac{\sigma}{\sigma_{\mathrm{r}}}\right)^{p-2 r}\left\{1-\left[1-(1+k+2 r) h_{\mathrm{d}}\left(\frac{\sigma}{\sigma_{\mathrm{r}}}\right)^{p} \frac{t}{t_{\mathrm{d}}}\right]^{\frac{1+k+2 r-p}{1+k+2 r}}\right\},
$$

josta saadaan virumismurtovenymäksi

$$
\varepsilon_{\mathrm{c}, \text { rup }}=\frac{1}{1+k+2 r-p} \cdot \frac{t_{\mathrm{d}} h_{\mathrm{c}}}{t_{\mathrm{c}} h_{\mathrm{d}}}\left(\frac{\sigma}{\sigma_{\mathrm{r}}}\right)^{p-2 r} .
$$




\section{Monkman-Grant hypoteesi}

Useiden metallien ja metalliseosten virumiskokeista on havaittu, että minimivirumisnopeuden ja virumismurtoajan tulo on vakio [31, 26], eli

$$
\dot{\varepsilon}_{\min }^{\mathrm{c}} t_{\text {rup }}=\text { vakio. }
$$

Tätä parametria kutsutaan Monkman-Grant parametriksi ja se esitetään joskus myös yleistetyssä muodossa

$$
C_{\mathrm{MG}}=\left(\dot{\varepsilon}_{\text {min }}^{\mathrm{c}}\right)^{m} t_{\mathrm{rup}}
$$

jossa potenssi $m$ vaihtelee välillä $0,8-1,0$. Monkman-Grant parametrin arvo on likimain virumismurtovenymän suuruinen

$$
C_{\mathrm{MG}} \lesssim \varepsilon_{\text {rup }}
$$

Edellä esitetylle mallille Monkman-Grant parametrilla $(m=1)$ on täten lauseke

$$
C_{\mathrm{MG}}=\dot{\varepsilon}_{\min }^{\mathrm{c}} t_{\mathrm{rup}}=\frac{1}{1+k+2 r} \frac{t_{\mathrm{d}} h_{\mathrm{c}}}{t_{\mathrm{c}} h_{\mathrm{d}}}\left(\frac{\sigma}{\sigma_{\mathrm{r}}}\right)^{p-2 r} .
$$

Monkman-Grant parametrin on todettu olevan useille metalleille miltei riippumaton lämpötilasta ja jännityksestä. Jännityksestä ja lämpötilasta riippumattomuus toteutuu mikäli ehdot

$$
p=2 r \quad \text { ja } \quad \frac{1}{1+k+2 r} \frac{t_{\mathrm{d}} h_{\mathrm{c}}}{t_{\mathrm{c}} h_{\mathrm{d}}}=\text { vakio }
$$

toteutuvat.

\section{Malli 2}

Tarkastellaan seuraavassa modifioitua mallia jossa vaurion dissipaatiopotentiaalia (48) on muutettu siten, että sen tuottama vaurionkehitys on yhteensopiva Monkman-Grant hypoteesin (74) kanssa. Ehdon (78) perusteella valitaan vaurion dissipaatiopotentiaaliksi lauseke

$$
\varphi_{\mathrm{d}}(Y ; T, \omega)=\frac{h_{\mathrm{c}}(T)}{\left(\frac{1}{2} p+1\right)(1+k+p)} \frac{Y_{\mathrm{r}}}{t_{\mathrm{d}} \omega^{k}}\left(\frac{Y}{Y_{\mathrm{r}}}\right)^{\frac{1}{2} p+1}
$$

josta seuraa eheysmuuttujan evoluutioyhtälöksi

$$
\dot{\omega}=-\frac{h_{\mathrm{c}}}{(1+k+p) t_{\mathrm{d}} \omega^{k}}\left(\frac{Y}{Y_{\mathrm{r}}}\right)^{\frac{1}{2} p} .
$$

Valitsemalla viitejännitykseksi $\sigma_{\mathrm{rd}}=\sigma_{\mathrm{r}}=\sigma_{\mathrm{y} 0}$, saa evoluutioyhtälö (80) yksidimensioisessa tapauksessa muodon

$$
\dot{\omega}=-\frac{h_{\mathrm{c}}}{(1+k+p) t_{\mathrm{d}} \omega^{k+p}}\left(\frac{\sigma}{\sigma_{\mathrm{r}}}\right)^{p}
$$

josta vakiojännityksen alaisessa virumiskokeessa saadaan integroimalla eheydelle esitys

$$
\omega=\left[1-h_{\mathrm{c}}\left(\frac{\sigma}{\sigma_{\mathrm{r}}}\right)^{p} \frac{t}{t_{\mathrm{d}}}\right]^{1 /(1+k+p)},
$$


ja virumismurtoajaksi saadaan

$$
t_{\text {rup }}=\frac{t_{\mathrm{d}}}{h_{\mathrm{c}}}\left(\frac{\sigma}{\sigma_{\mathrm{r}}}\right)^{-p}
$$

Integroimalla konstitutiivinen yhtälö (65) saadaan vakiojännityksen alaisen virumisvenymälle esitys

$$
\varepsilon_{\mathrm{c}}=\frac{1+k+p}{1+k}\left(\frac{t_{\mathrm{d}}}{t_{\mathrm{c}}}\right)\left\{1-\left[1-h_{\mathrm{c}}\left(\frac{\sigma}{\sigma_{\mathrm{r}}}\right)^{p} \frac{t}{t_{\mathrm{d}}}\right]^{\frac{1+k}{1+k+p}}\right\},
$$

ja josta saadaan virumismurtovenymäksi

$$
\varepsilon_{\mathrm{c}, \text { rup }}=\frac{1+k+p}{1+k} \cdot \frac{t_{\mathrm{d}}}{t_{\mathrm{c}}}
$$

Mallin ennustama arvo Monkman-Grant parametrille on siten

$$
\dot{\varepsilon}_{\mathrm{c}, \min }=\frac{h_{\mathrm{c}}}{t_{\mathrm{c}}}\left(\frac{\sigma}{\sigma_{\mathrm{r}}}\right)^{p}, \quad t_{\mathrm{rup}}=\frac{t_{\mathrm{d}}}{h_{\mathrm{c}}}\left(\frac{\sigma}{\sigma_{\mathrm{r}}}\right)^{-p}, \quad \Rightarrow \quad C_{\mathrm{MG}}=\frac{t_{\mathrm{d}}}{t_{\mathrm{c}}} .
$$

\section{Larson-Miller parametri}

Frank Larson ja James Miller esittivät vuonna 1952 [21] seuraavan relaation virumismurtoajan ja lämpötilan välille tietyllä jännitystasolla:

$$
P_{\mathrm{LM}}=T\left[C+\ln \left(t_{\mathrm{rup}}\right)\right]
$$

jossa parametria $C$ pidetään usein vakiona. Yhtälön (87) muoto on luonnollisesti epätyydyttävä, sillä parametrin $C$ arvo riippuu käytetyistä yksiköistä. Vastaava relaatio voidaan elegantimmin johtaa lähtemällä esimerkiksi virumismurtoajan (83) lausekkeesta

$$
\frac{t_{\mathrm{rup}}}{t_{\mathrm{d}}}=\frac{1}{h_{\mathrm{c}}}\left(\frac{\sigma}{\sigma_{\mathrm{r}}}\right)^{-p}=\exp (Q / R T)\left(\frac{\sigma}{\sigma_{\mathrm{r}}}\right)^{-p} .
$$

Tästä saadaan ottamalla yhtälön molemmista puolista logaritmit

$$
\frac{Q}{R}=T\left[p \ln \left(\frac{\sigma}{\sigma_{\mathrm{r}}}\right)+\ln \left(\frac{t_{\mathrm{rup}}}{t_{\mathrm{d}}}\right)\right]=\tilde{P}_{\mathrm{LM}},
$$

joka on suositeltavampi muoto Larson-Miller parametrista antaen samalla fysikaalisen tulkinnan parametrin arvolle. Larson-Miller parametria voidaan käyttää virumismurtoajan karkeassa estimoinnissa.

\section{Materiaaliparametrien määritys}

Esitetään seuraavassa materiaaliparametrien määritys sovitettuna T24-teräksen, 7CrMoVTiB1010, valmistajan materiaalidataan [2]. Tässä työssä ei materiaalin isotrooppista lujittumista ole mallinnettu, eli $\psi_{\mathrm{p}} \equiv 0$, joten $\sigma_{\mathrm{rc}}=\sigma_{\mathrm{y} 0}(T)$. 
Taulukko 1. Teräksen T24 dataan sovitetut mallin parametrien arvot.

\begin{tabular}{lclc}
\hline parametri & arvo & parametri & arvo \\
\hline$t_{\mathrm{c}}[\mathrm{s}]$ & 3039.9 & $p_{\mathrm{r}}$ & 14.766 \\
$t_{\mathrm{d}}[\mathrm{s}]$ & 37.768 & $a$ & -4.804 \\
$q_{\mathrm{c}}[\mathrm{K}]$ & 7137.6 & $r_{\mathrm{r}}$ & 7.545 \\
$q_{\mathrm{d}}[\mathrm{K}]$ & 9350.1 & $b$ & -5.201 \\
\hline
\end{tabular}

\section{Malli 1}

Tarkastellaan ensin mallin (52) ja (53) mukaista tapausta, jossa Monkman-Grant oletusta ei pakoteta a priori, vaan katsotaan kuinka se toteutuu, kun malli kalibroidaan näiden parametrien suhteen valmistajan materiaalidataan nähden [2].

Potenssien $p$ ja $r$ lämpötilariippuvuudelle voidaan olettaa lineaariset lausekkeet

$$
p(T)=p_{\mathrm{r}}\left[1+a\left(T-T_{\mathrm{r}}\right) / T_{\mathrm{r}}\right], \quad r(T)=r_{\mathrm{r}}\left[1+b\left(T-T_{\mathrm{r}}\right) / T_{\mathrm{r}}\right] .
$$

Estimoitavia parametreja ovat siis aikaparametrit $t_{\mathrm{c}}, t_{\mathrm{d}}$, dimensiottomat potenssit $p_{\mathrm{r}}, r_{\mathrm{r}}$ sekä aktivaatioenergiat $Q_{\mathrm{c}}$ ja $Q_{\mathrm{d}}$ ja potenssien dimensiottomat lämpötilariippuvuuskertoimet $a, b$. Kalibrointia varten oletetaan vielä, että $k+2 r(T)=p(T)+2[23$, Luku 3.3.3]. Tästä seuraa $k=2$, jos $2 r(T)=p(T)$.

Varsinainen kalibrointi suoritetaan ratkaisemalla yhtälöiden (65) ja (70) avulla ne parametrien arvot, jotka parhaiten sovittavat kehitetyn mallin valmistajan dataan nähden. Käytettävissä on valmistajan [2] virumiskokeiden testidata kolmessa lämpötilassa $\left(500^{\circ} \mathrm{C}\right.$, $550^{\circ} \mathrm{C}$ ja $600^{\circ} \mathrm{C}$ ) minimivirumisnopeuksille ja virumislujuuksille. Tällä lämpötilavälillä teräksen T24 myötöjännitys voidaan esittää lineaarisella relaatiolla

$$
\sigma_{\mathrm{r}}=\sigma_{\mathrm{y} 0}(T)=\sigma^{*}-c T
$$

jossa parametreilla $\sigma^{*}$ ja $c$ on arvot $\sigma^{*}=1123 \mathrm{MPa}$ ja $c=-1 \mathrm{MPa} / \mathrm{K}$. Mallin ennuste valmistajan dataan nähden on esitetty kuvassa 9. Mallin 1 parametrien arvot on esitetty taulukossa 1.

Taulukossa 1 aktivaatioenergiat $q_{\mathrm{c}}$ ja $q_{\mathrm{d}}$ on normeerattu yleisellä kaasuvakiolla $R$. Saadut materiaaliparametrit ovat suuruudeltaan realistisia ja $p=2 r$ toteutuu tyydyttävällä tarkkuudella viitelämpötilassa $T_{\mathrm{r}}=773 \mathrm{~K}$. Lisäksi havaitaan, että lämpötilan noustessa, jolloin kokeiden jännitystaso alenee, eksponenttien $p$ ja $r$ arvo alenee jyrkästi. Tämä on tyypillistä useille metalleille, katso [10, Taulukko 3.1].

Monkman-Grant -parametrin riippumattomuus jännityksestä ja lämpötilasta esitetään lineaarisella asteikolla kuvassa 7. Hypoteesin toteutuma ei näytä erityisen hyvältä. Toisaalta logaritmisella asteikolla tarkasteltuna mallin antamat tulokset näyttävät paremmin yhteensopivilta Monkman-Grant -hypoteesin kanssa, kuva 8.

\section{Malli 2}

Vastaavalla tavalla menetellen saadaan mallin 2 parametrien arvot määritettyä ja ne on esitetty taulukossa 2. Tässä virumismurtomallissa on kimmovakioiden ja myötöjännityksen lisäksi vain neljä määritettävää parametria, ja näistä yksi on lämpötilariippuva. Malli 2 toteuttaa Monkmann-Grant -hypoteesin. Mallin ennustaman murtovenymän ja Monkmann- 


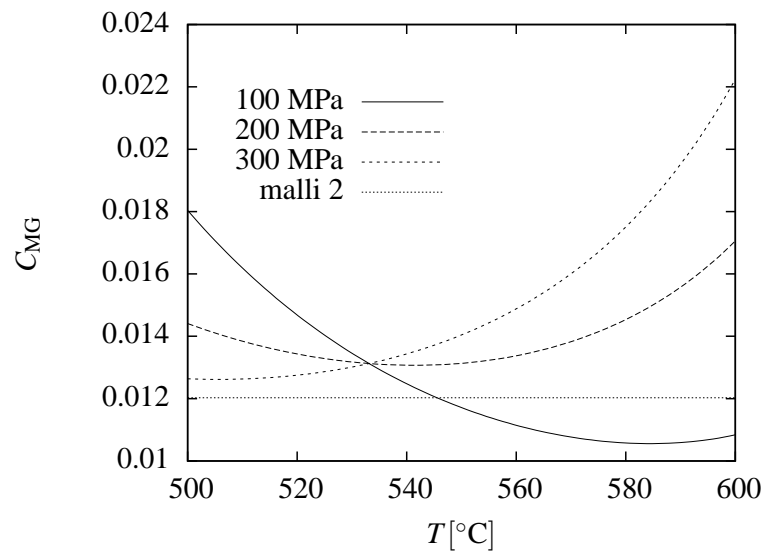

Kuva 7. Monkman-Grant -parametri (74) materiaaliparametrien kalibroinnin lämpötila-alueella $\left(500^{\circ}, 600^{\circ}\right)$.

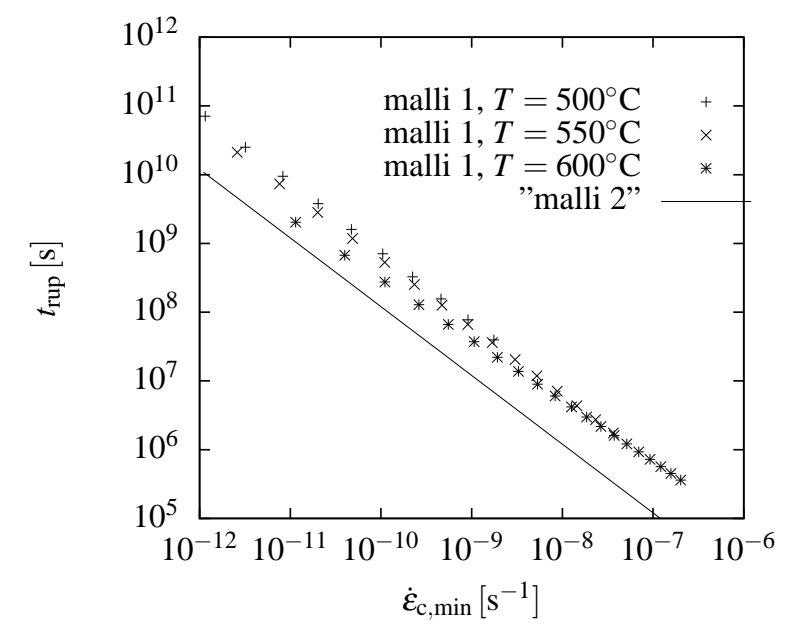

Kuva 8. Mallien ennustamat virumismurtoajat eri jännitystasoilla ja lämpötiloissa minimivirumisnopeuden funktiona. Mallin 2 tulokset ovat riippumattomia lämpötilasta. 
Taulukko 2. Ehdot (78) toteuttavat teräksen T24 dataan sovitetut mallin parametrien arvot.

\begin{tabular}{lclc}
\hline parametri & arvo & parametri & arvo \\
\hline$t_{\mathrm{c}}[\mathrm{s}]$ & 24445.1 & $p_{\mathrm{r}}=p\left(500^{\circ} \mathrm{C}\right)$ & 14.788 \\
$t_{\mathrm{d}}[\mathrm{s}]$ & 294.06 & $a$ & -4.9984 \\
$q_{\mathrm{c}}[\mathrm{K}]$ & 5539.1 & $p\left(600^{\circ} \mathrm{C}\right)$ & 5.228 \\
\hline
\end{tabular}

Grant -parametrin suhde on esitetty kuvassa 10, josta havaitaan, että mallin ennustama murtovenymä pienenee lämpötilan kasvaessa.

\section{Lämmöntuottotermien tarkastelua}

Palataan tutkimaan lämmönjohtumisyhtälön (39) deformaatiosta aiheutuvien termien keskinäisiä suuruussuhteita. Merkitään muodonmuutosten ja vaurion aikaansaamaa lämmöntuottonopeutta tilavuutta kohden

$$
\rho \mathcal{R}_{\text {mech }}=\boldsymbol{\sigma}: \dot{\varepsilon}_{\mathrm{c}}+\rho T \frac{\partial^{2} \psi}{\partial \varepsilon_{\mathrm{te}} \partial T}: \dot{\varepsilon}_{\mathrm{te}}+\left(\rho T \frac{\partial^{2} \psi}{\partial \omega \partial T}-Y\right) \dot{\omega}+\left(\rho T \frac{\partial^{2} \psi}{\partial \kappa \partial T}-K\right) \dot{\kappa},
$$

joka voidaan ryhmitellä

$$
\begin{aligned}
\rho \mathcal{R}_{\mathrm{mc}} & =\boldsymbol{\sigma}: \dot{\varepsilon}_{\mathrm{c}}-K \dot{\kappa} \\
\rho \mathcal{R}_{\mathrm{md}} & =-Y \dot{\omega} \\
\rho \mathcal{R}_{\mathrm{mte}} & =\rho T \frac{\partial^{2} \psi}{\partial \varepsilon_{\mathrm{te}} \partial T}: \dot{\varepsilon}_{\mathrm{te}}=T \boldsymbol{\varepsilon}_{\mathrm{te}}: \frac{\mathrm{d} \boldsymbol{C}_{\mathrm{e}}}{\mathrm{d} T}: \dot{\boldsymbol{\varepsilon}}_{\mathrm{te}} \\
\rho \mathcal{R}_{\mathrm{mtd}} & =\rho T \frac{\partial^{2} \psi}{\partial \omega \partial T} \dot{\omega}=T \frac{\partial Y}{\partial T} \dot{\omega} \\
\rho \mathcal{R}_{\mathrm{mtc}} & =\rho T \frac{\partial^{2} \psi}{\partial \kappa \partial T} \dot{\kappa}=T \frac{\partial K}{\partial T} \dot{\kappa} .
\end{aligned}
$$

Termit (94)-(96) kuvaavat lämmöntuottoa, mikäli Helmholtzin ominaisvapaaenergiassa esiintyvät mekaanista käyttäytymistä kuvaavat materiaaliparametrit riippuvat lämpötilasta.

Tarkastellaan edellä esitettyjä lämmöntuottonopeuksia yksiakselisessa vetojännitystilassa. Tällöin saadaan lausekkeet

$$
\begin{aligned}
\rho \mathcal{R}_{\mathrm{mc}} & \approx \frac{\sigma_{\mathrm{y} 0} h_{\mathrm{c}}}{t_{\mathrm{c}}}\left(\frac{\sigma}{\omega \sigma_{\mathrm{rc}}}\right)^{p}, \quad \rho \mathcal{R}_{\mathrm{md}}=\frac{h_{\mathrm{d}} \sigma_{\mathrm{rd}}^{2}}{t_{\mathrm{d}} \omega^{k-1} E}\left(\frac{\sigma}{\omega \sigma_{\mathrm{rd}}}\right)^{2 r+2}, \quad \rho \mathcal{R}_{\mathrm{mte}} \approx T \frac{\mathrm{d} E}{\mathrm{~d} T} \varepsilon_{\mathrm{te}} \dot{\varepsilon}_{\mathrm{te}} \\
\rho \mathcal{R}_{\mathrm{mtd}} & =-\frac{1}{2} T \frac{\mathrm{d} E}{\mathrm{~d} T} \frac{h_{\mathrm{d}}}{t_{\mathrm{d}} \omega^{k}}\left(\frac{\sigma_{\mathrm{rd}}}{E}\right)^{2}\left(\frac{\sigma}{\omega \sigma_{\mathrm{rd}}}\right)^{2 r+2}, \quad \rho \mathcal{R}_{\mathrm{mtc}}=T \frac{\partial K}{\partial T} \dot{\varepsilon}_{\mathrm{c}}
\end{aligned}
$$

Oletetaan kimmokertoimen lämpötilariippuvuus lineaariseksi tarkastellulla lämpötila-alueella

$$
E(T)=E\left(T_{0}\right)\left(1+C_{E} \frac{T-T_{0}}{T_{\mathrm{m}}}\right)
$$

jossa $T_{\mathrm{m}}$ on materiaalin sulamislämpötila. Odotettavasti termi $\mathcal{R}_{\mathrm{mc}}$ on merkittävin ja tarkastellaankin muiden termien suuruutta tähän verrattuna. Otaksutaan yksinkertaisuuden 


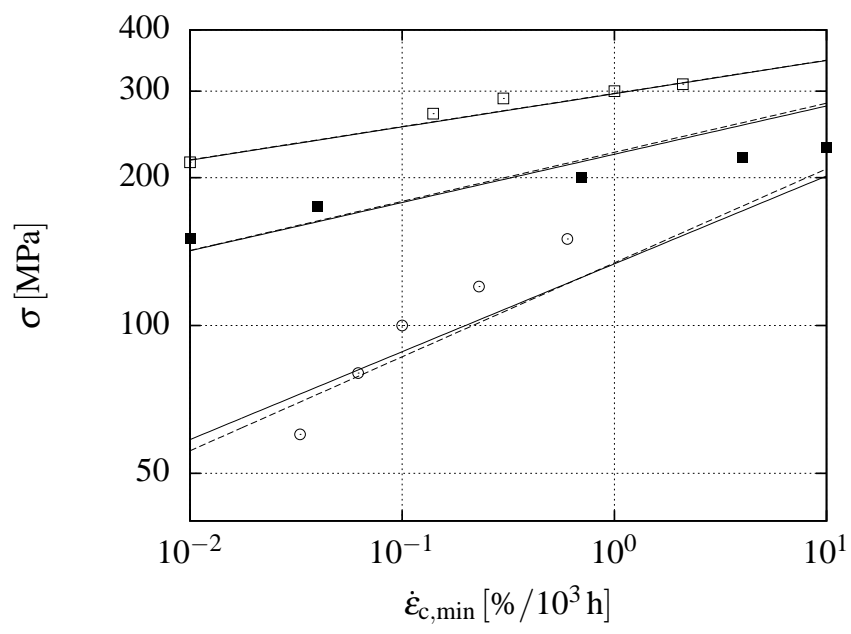

(a)

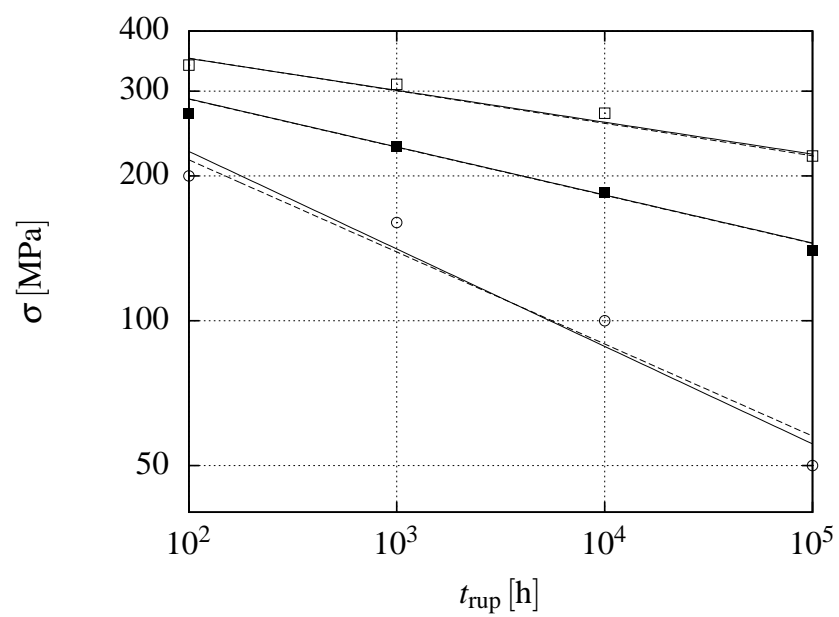

(b)

Kuva 9. Mallien kalibroidut ennusteet valmistajan dataan [2] nähden materiaalille T24: (a) minimivirumisnopeudet ja (b) virumislujuudet. Mallin 1 tulokset on piirretty ehyellä viivalla ja mallin 2 katkoviivalla. Ylimmät kuvaajat liittyvät lämpötilaan $500^{\circ} \mathrm{C}$, keskimmäiset $550^{\circ} \mathrm{C}$ ja alimmat $600^{\circ} \mathrm{C}$. 


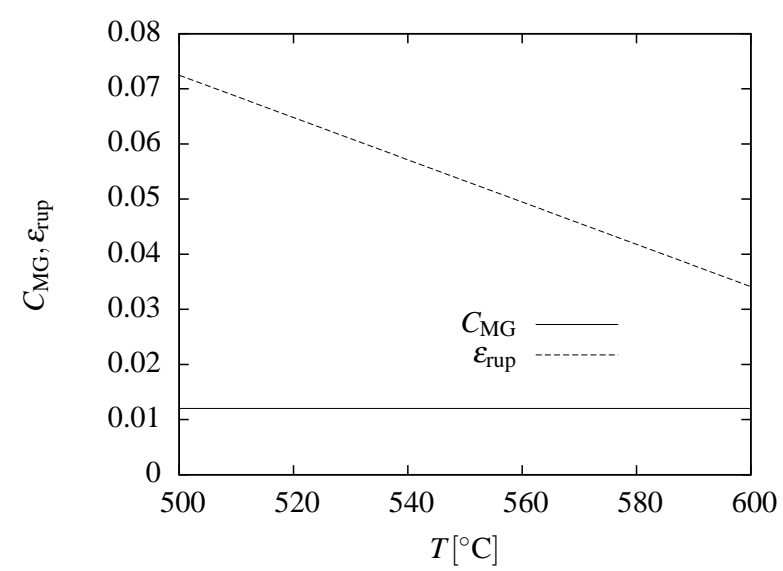

Kuva 10. Mallin 2 ennustama murtovenymä ja Monkmann-Grant -parametri.

vuoksi ehdot $\sigma_{\mathrm{rd}}=\sigma_{\mathrm{rc}}=\sigma_{\mathrm{y} 0}$, tällöin lujittumisparametri $K \equiv 0$. Mikäli lausekkeet lasketaan lämpötilan $T_{0}$ ympäristössä, saadaan suhteet

$$
\begin{aligned}
\frac{\mathcal{R}_{\mathrm{md}}}{\mathcal{R}_{\mathrm{mc}}} & =\frac{t_{\mathrm{c}} h_{\mathrm{d}}}{t_{\mathrm{d}} h_{\mathrm{c}}}\left(\frac{\sigma}{E}\right)\left(\frac{\sigma}{\sigma_{\mathrm{y} 0}}\right) \frac{1}{\omega^{k+1}}\left(\frac{\sigma}{\omega \sigma_{\mathrm{y}}}\right)^{2 r-p}, \\
\frac{\mathcal{R}_{\mathrm{mte}}}{\mathcal{R}_{\mathrm{mc}}} & =C_{E} \frac{T}{T_{\mathrm{m}}} \frac{\sigma}{\omega \sigma_{\mathrm{y} 0}} \frac{t_{\mathrm{c}} \dot{\varepsilon}^{\mathrm{te}}}{h_{\mathrm{c}}}, \\
\frac{\mathcal{R}_{\mathrm{mtd}}}{\mathcal{R}_{\mathrm{mc}}} & =C_{E} \frac{t_{\mathrm{c}} h_{\mathrm{d}}}{t_{\mathrm{d}} h_{\mathrm{c}}} \frac{1}{\omega^{k+1}}\left(\frac{\sigma}{\omega E\left(T_{0}\right)}\right) \frac{T}{T_{\mathrm{m}}} .
\end{aligned}
$$

Mikäli tälle lämpötilalle valitaan $500^{\circ} \mathrm{C}$, eli $T_{0}=773 \mathrm{~K}$, ja ottaen huomioon teräksen sulamislämpötila $T_{\mathrm{m}} \approx 1800 \mathrm{~K}$, ja kimmokertoimen lämpötilariippuvuusparametri $C_{E} \approx$ -1 , sekä valitsemalla taulukossa 1 esitetyt arvot muille materiaaliparametreille, saadaan suuruusluokka-arviot

$$
\frac{t_{\mathrm{c}}}{t_{\mathrm{d}}} \approx 80, \quad \frac{h_{\mathrm{d}}}{h_{\mathrm{c}}} \approx 0.057, \text { joten } \frac{t_{\mathrm{c}} h_{\mathrm{d}}}{t_{\mathrm{d}} h_{\mathrm{c}}} \frac{T_{0}}{T_{\mathrm{m}}} \approx 2 .
$$

Virumisessa termoelastinen venymänopeus häviää, ja ottaen huomioon, että tarkasteltaessa tilannetta vaurioitumisen alkuvaiheessa $\omega \lesssim 1$ ja $p=2 r$, saadaan

$$
\begin{aligned}
& \frac{\mathcal{R}_{\mathrm{md}}}{\mathcal{R}_{\mathrm{mc}}} \approx 4.6\left(\frac{\sigma}{E\left(T_{0}\right)}\right)\left(\frac{\sigma}{\sigma_{\mathrm{y} 0}}\right) \sim \frac{\sigma}{E\left(T_{0}\right)}, \\
& \frac{\mathcal{R}_{\mathrm{mtd}}}{\mathcal{R}_{\mathrm{mc}}} \approx 2\left(\frac{\sigma}{E\left(T_{0}\right)}\right) \sim \frac{\sigma}{E\left(T_{0}\right)} .
\end{aligned}
$$

Näin on tullut osoitettua, että virumisen aiheuttama lämmöntuotto on useita kertaluokkia vaurioitumisen aiheuttamaa lämmöntuottoa suurempi. Mielenkiintoista on kuitenkin se, että termien $\mathcal{R}_{\text {md }}$ ja $\mathcal{R}_{\text {mtd }}$ vaikutus on samaa suuruusluokkaa.

Virumisprosessin aiheuttama lämmöntuotto on kuitenkin merkityksetön. Lämpötilalla on kuitenkin merkittävä vaikutus sen suuruuteen: $500^{\circ} \mathrm{C}: n$ lämpötilassa se on luokkaa 3 $\mathrm{mW} / \mathrm{m}^{3}$ ja vastaavasti $7 \mathrm{~W} / \mathrm{m}^{3} 600^{\circ} \mathrm{C}$ :ssa. 


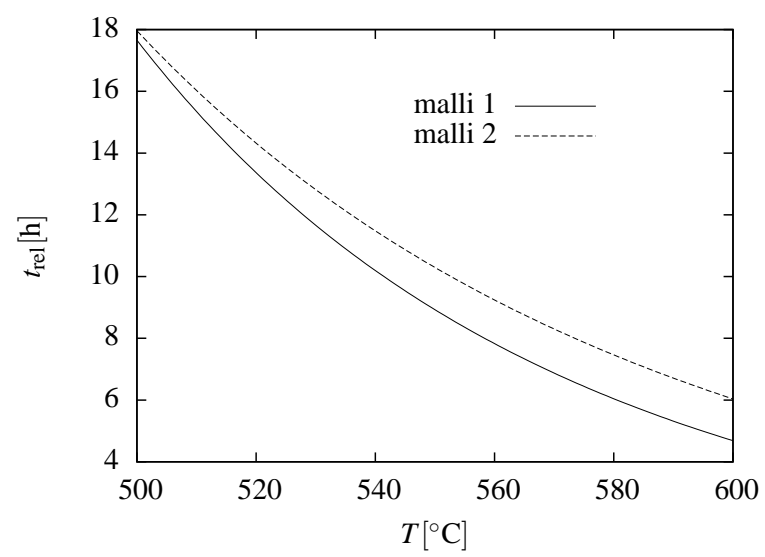

Kuva 11. Relaksaatioaika $t_{\text {rel }}$ materiaaliparametrien kalibroinnin lämpötila-alueella $\left(500^{\circ}, 600^{\circ}\right)$.

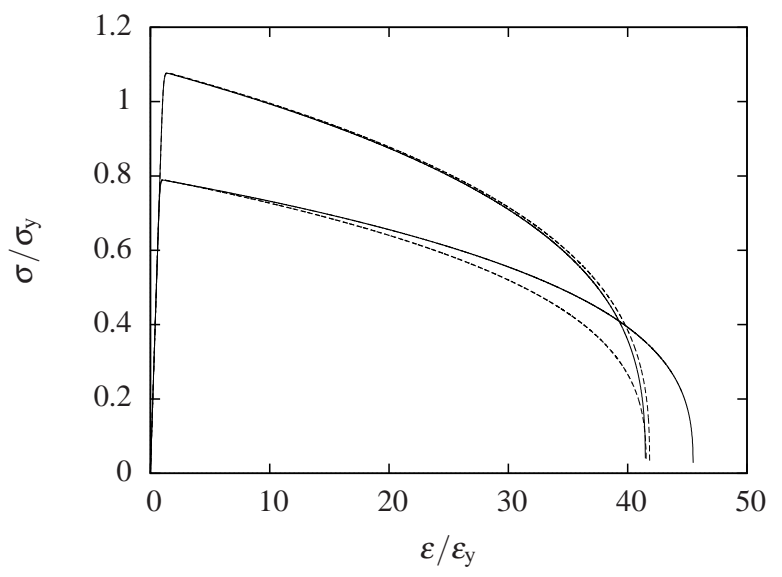

Kuva 12. Mallien ennuste vakionopeudella tehdyssä vetokokeessa lämpötilassa 500. Ylemmät käyrät ovat vetonopeudella $\dot{\varepsilon}=10^{-7} 1 / \mathrm{s}$ ja alemmat $\dot{\varepsilon}=10^{-9} 1 / \mathrm{s}$. Mallin 1 vaste on piirretty ehyellä viivalla ja mallin 2 vastaavasti katkoviivalla.

\section{Mallien vertailua}

\section{Relaksaatioaika}

Kuvassa 11 on esitetty relaksaatioaika (66) tunteina materiaalien kalibroinnin lämpötilaalueella $500^{\circ} \mathrm{C}-600^{\circ} \mathrm{C}$. Relaksaatioajan lyheneminen on huomattava. Malli 2 ennustaa hieman suuremman relaksaatioajan.

\section{Vakionopeudella tehtävä vetokoe}

Kuvassa 12 on esitetty molempien mallien vaste vakionopeudella tehdyssä vetokokeessa. Koska mallissa ei ole varsinaista myötölujittumista, vaurionkehitys aiheuttaa myötöpehmenemistä jo melko pienillä venymän arvoilla. Mallin 2 tulokset murtovenymälle ovat riippumattomia vetonopeudesta. 


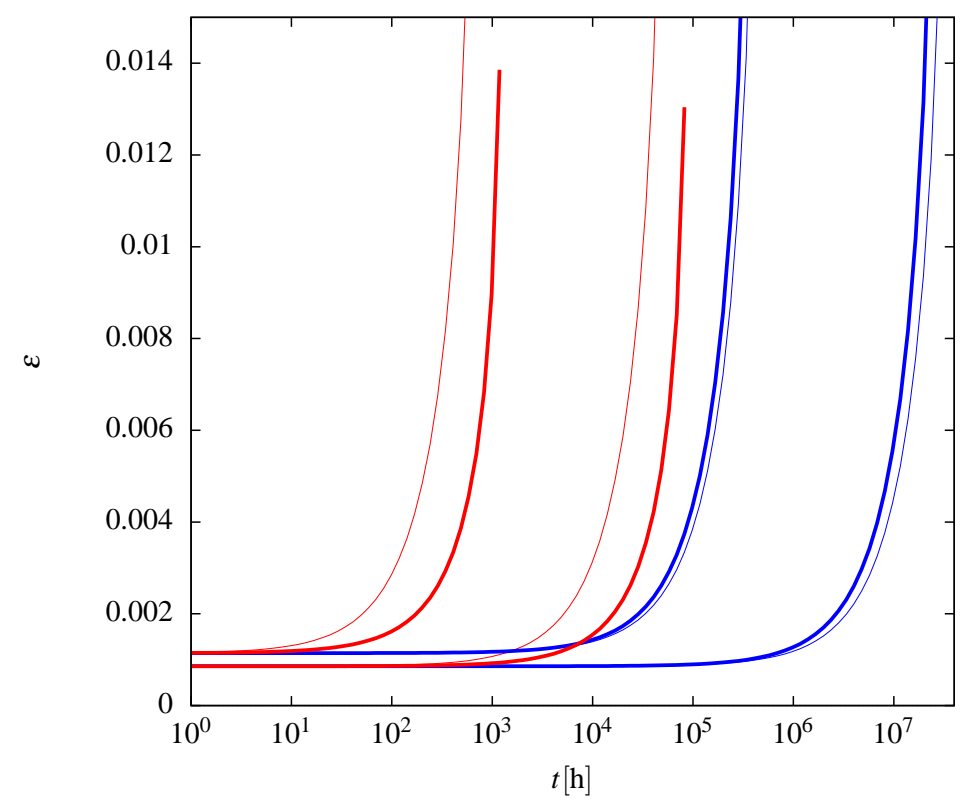

Kuva 13. Virumisvetokoe lämpötilassa $500^{\circ} \mathrm{C}$ ja $600^{\circ} \mathrm{C}$ vakiojännityksen $150 \mathrm{MPa}$ ja $200 \mathrm{MPa}$ alaisena. Korkeamman lämpötilan tulokset on esitetty punaisella ja mallin 2 tulokset on esitetty paksummalla viivalla.

\section{Vakiojännityksen alainen virumiskoe}

Kuvassa 13 on esitetty molempien mallien venymän kehitys virumiskokeessa jännitysten arvoilla $150 \mathrm{MPa}$ ja $200 \mathrm{MPa}$ lämpötiloissa $500^{\circ} \mathrm{C}$ ja $600^{\circ} \mathrm{C}$.

Edellä on tarkasteltu yksiulotteista tapausta, jossa ainoana jännityskomponenttina on normaalijännitys $\sigma_{0}$. Mikäli jännityksenä on saman tehollisen jännityksen $\bar{\sigma}$ antava leikkausjännitys $\tau_{0}=\sigma_{0} / \sqrt{3}$, on virumismurtoaika huomattavasti suurempi. Näiden kuormitusten aiheuttamien virumismurtoaikojen suhde on ensimmäiselle mallille

$$
\frac{t_{\mathrm{rup}}\left(\tau_{0}=\sigma_{0} / \sqrt{3}\right)}{t_{\mathrm{rup}}\left(\sigma_{0}\right)}=\left(\frac{2}{3}(1+\nu)\right)^{-s}
$$

jossa eksponentti $s=r$ mallille 1 ja vastaavasti mallille $2 s=\frac{1}{2} p$. Mikäli Poisson'n vakiolla on arvo 0,3 , saa suhde (105) arvoja $2,2-3,1$ välillä potenssin $r$ tai $p / 2$ saadessa arvoja välillä $3-8$. On kuitenkin huomautettava, että suhteen (105) arvo riippuu suuresti Poissonin vakion arvosta.

\section{Sylinteriputken lämpösyklaus}

Tarkastellaan kuvan 14 mukaisesti kitkattomasti päätylevyihin tukeutuvaa ympyräsylinteriä, jota kuormittaa jatkuvasti vaikuttava sisäinen paine $p=15 \mathrm{MPa}$, sekä kuvan mukainen lämpösykli, jossa $T_{\text {cold }}=20^{\circ} \mathrm{C}, T_{\text {hot }}=550^{\circ} \mathrm{C}$. Käyntiprosessin ylös- ja alasajoajat ovat kumpikin 350 minuuttia, pitoaika yksi kuukausi ja seisokkiaika yksi viikko. Putken sisäsäde on $R=350 \mathrm{~mm}$ ja seinämän paksuus $h=30 \mathrm{~mm}$.

Tehtävä voidaan muotoilla yhden jännityskomponentin $\sigma_{z}$ ja eheysmuuttujan $\omega$ muodostamaksi differentiaaliyhtälösysteemiksi. Kehän suuntainen jännityskomponentti $\sigma_{\phi}$ on vakio $\sigma_{\phi}=p R / h \approx 175 \mathrm{MPa}$. Tasojännitystilassa konstitutiivinen yhtälö on

$$
\left(\begin{array}{c}
\sigma_{z} \\
\sigma_{\phi}
\end{array}\right)=\frac{\omega E}{1-\nu^{2}}\left(\begin{array}{cc}
1 & \nu \\
\nu & 1
\end{array}\right)\left(\begin{array}{c}
\varepsilon_{z}^{\mathrm{e}} \\
\varepsilon_{\phi}^{\mathrm{e}}
\end{array}\right)
$$




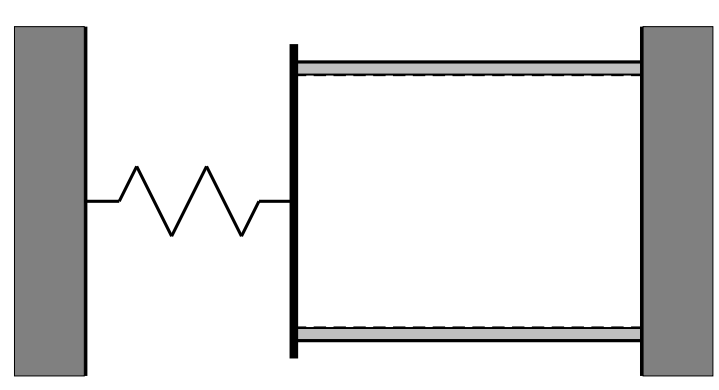

(a)

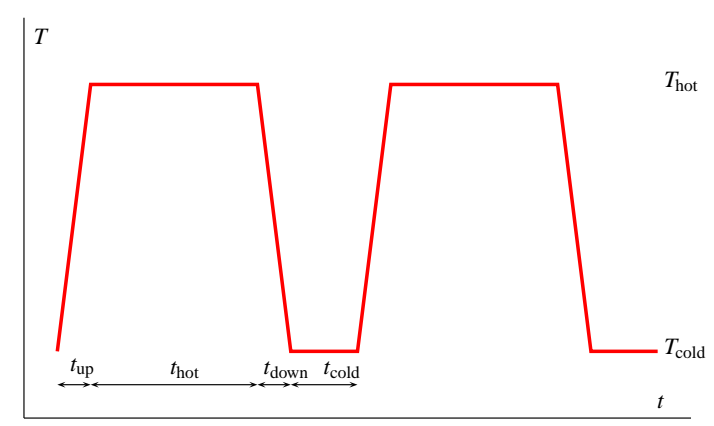

(b)

Kuva 14. Sylinteriputken lämpösyklaus.

jossa

$$
\varepsilon_{z}^{\mathrm{e}}=\varepsilon_{z}-\varepsilon_{z}^{\mathrm{c}}-\varepsilon_{z}^{\mathrm{th}}, \quad \text { ja } \quad \varepsilon_{\phi}^{\mathrm{e}}=\varepsilon_{\phi}-\varepsilon_{\phi}^{\mathrm{c}}-\varepsilon_{\phi}^{\mathrm{th}} .
$$

Kehän suuntainen muodonmuutoskomponentti voidaan ratkaista kehäjännityksen ja aksiaalisen elastisen muodonmuutoskomponentin avulla, jolloin saadaan konstitutiivinen yhtälö

$$
\sigma_{z}=\omega E\left(\varepsilon_{z}-\varepsilon_{z}^{\mathrm{c}}-\varepsilon_{z}^{\mathrm{th}}\right)+\nu \sigma_{\phi} .
$$

Tämän nopeusmuotoinen esitysmuoto on

$$
\dot{\sigma}_{z}=\omega E\left(\dot{\varepsilon}_{z}-\dot{\varepsilon}_{z}^{\mathrm{c}}-\dot{\varepsilon}_{z}^{\mathrm{th}}\right)+\left(\frac{\dot{\omega}}{\omega}+\frac{\dot{E}}{E}\right)\left(\sigma_{z}-\nu \sigma_{\phi}\right)+\nu \dot{\sigma}_{\phi}+\dot{\nu} \sigma_{\phi} .
$$

Oletetaan, että kuvan 14a mukaisen kimmoisan jousen voima on lausuttavissa

$$
F_{z}=\xi E A \frac{\Delta L}{L}=-\xi E A \varepsilon_{z}
$$

jossa $\varepsilon_{z}$ on sylinterin aksiaalinen muodonmuutos. Täten jousen "jännitys" voidaan ilmaista $\sigma_{z}=-\xi E \varepsilon_{z}$ ja tällöin $\varepsilon_{z}=-\sigma_{z} /(\xi E)$. Aksiaalisen jännityksen differentiaaliyhtälöksi saadaan siten

$$
\left(1+\frac{\omega}{\xi}\right) \dot{\sigma}_{z}=-\omega E\left(\dot{\varepsilon}_{z}^{\mathrm{c}}+\dot{\varepsilon}_{z}^{\mathrm{th}}\right)+\left(\frac{\dot{\omega}}{\omega}+\frac{\dot{E}}{E}\right)\left(\sigma_{z}-\nu \sigma_{\phi}\right)+\nu \dot{\sigma}_{\phi}+\dot{\nu} \sigma_{\phi} .
$$

Yhdessä vaurion evoluutioyhtälön (53) kanssa voidaan systeemin tila ratkaista.

Kuvassa 15a on esitetty virumismurtoon tarvittavien lämpösyklien lukumäärä jousen jäykkyysparametrin $\xi$ funktiona. Vastaavasti b-kuvassa on esitetty von Misesin tehollinen jännitys $\bar{\sigma}=\sqrt{3 J_{2}}$ tapauksessa $\xi=2$. Analyysissä on Poisson'n vakio $\nu$ ja lämpöpitenemiskerroin $\alpha$ oletettu vakioiksi. Myötöjännitykselle on käytetty lämpötilasta riippuvaa arvoa $\sigma_{\mathrm{y} 0}(T)$ yhtälön (90) mukaisesti, kuitenkin siten, että lämpötilan laskiessa se on korkeintaan $450 \mathrm{MPa}$. Vaurionkehityksen viitejännityksenä on yhtälön (61) mukainen lauseke, jossa transitiolämpötila on $T_{\mathrm{tr}}=500^{\circ} \mathrm{C}$ ja muutosalueen leveysparametri $\Delta T=10^{\circ} \mathrm{C}$. Jännitysarvolle $\sigma_{\mathrm{f}}$ on käytetty arvoa $500 \mathrm{MPa}$. Yhtälösysteemi on integroitu eksplisiittisellä Eulerin menetelmällä käyttäen $5 \mathrm{~s}$ aika-askelta.

Jousen jäykkyydellä on huomattava vaikutus lämpösyklauksen kestoon. Varsin selvä muutos tapahtuu parametrin $\xi$ arvon 1 kohdalla. Tällöin jousen jäykkyys on yhtäsuuri putken kimmoisen aksiaalijäykkyyden kanssa. 


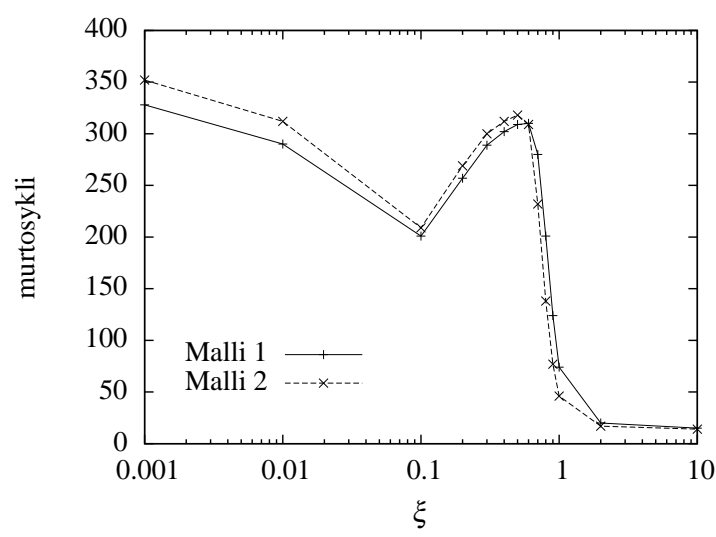

(a)

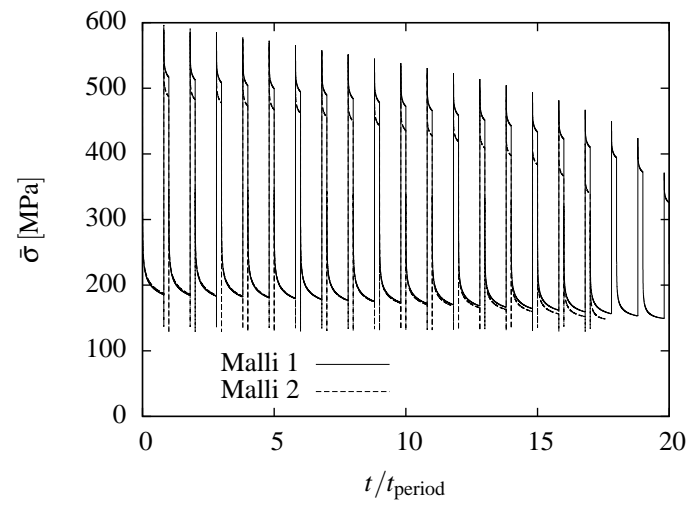

(b)

Kuva 15. Sylinteriputken lämpösyklaus. (a) Virumismurtoon tarvittavien syklien lukumäärä jäykkyysparametrin $\xi$ funktiona. (b) Von Misesin tehollinen jännitys $\bar{\sigma}$ tapauksessa $\xi=2$.

\section{Numeerinen ratkaisu elementtimenetelmällä}

\section{Implisiittinen Eulerin menetelmä}

Nopeusriippuville viskoplastisille materiaalimalleille implisiittiset ehdottomasti stabiilit integraattorit ovat suositeltavia. Tavanomaisten plastisten ja viskoplastisten mallien paikallisessa integrointipisteessä tapahtuvassa materiaalimallin integroimisessa implisiittinen Eulerin menetelmä on hyvin suosittu. Plastisen materiaalimallin tapauksessa se tunnetaan myös nimellä lähimmän pisteen menetelmä. Vaikka yksiaskelinen implisiittinen Eulerin menetelmä on asymptoottiselta tarkkuudeltaan vain ensimmäistä kertalukua, on sillä erittäin hyvät tarkkuusominaisuudet laskettaessa pitkillä, käytännössä usein käytettävillä aika-askeleilla [20].

Käyttäen matriisinotaatiota, konstitutiivinen malli (51)-(53) voidaan kirjoittaa muodossa

$$
\begin{aligned}
& \dot{\boldsymbol{\sigma}}=\boldsymbol{f}_{\sigma}(\boldsymbol{\sigma}, \omega), \\
& \dot{\omega}=f_{\omega}(\boldsymbol{\sigma}, \omega),
\end{aligned}
$$

jossa

$$
\begin{aligned}
\boldsymbol{f}_{\sigma}(\boldsymbol{\sigma}, \omega) & =\omega \boldsymbol{C}_{\mathrm{e}} \dot{\varepsilon_{\mathrm{e}}}+\dot{\omega} \boldsymbol{C}_{\mathrm{e}} \varepsilon_{\mathrm{e}}+\omega \dot{\boldsymbol{C}}_{\mathrm{e}} \varepsilon_{\mathrm{e}} \\
& =\omega \boldsymbol{C}_{\mathrm{e}}\left(\dot{\varepsilon}-\dot{\varepsilon_{\mathrm{th}}}-\dot{\varepsilon_{\mathrm{c}}}\right)+\left(\frac{\dot{\omega}}{\omega} \boldsymbol{C}_{\mathrm{e}}+\omega \dot{T} \frac{\partial \boldsymbol{C}_{\mathrm{e}}}{\partial T}\right) \boldsymbol{C}_{\mathrm{e}}^{-1} \boldsymbol{\sigma} \\
f_{\omega}(\boldsymbol{\sigma}, \omega) & =-\frac{B_{\mathrm{d}}}{t_{\mathrm{d}} \omega^{k}}\left(\frac{Y}{Y_{\mathrm{r}}}\right)^{r} .
\end{aligned}
$$

Tässä esitetyt mallit on ohjelmoitu Ansys-elementtimenetelmäohjelmaan USERMATaliohjelmaksi. Implementoinnista puuttuu kuitenkin termi

$$
\omega \dot{T} \frac{\partial \boldsymbol{C}_{\mathrm{e}}}{\partial T} \boldsymbol{C}_{\mathrm{e}}^{-1} \boldsymbol{\sigma}
$$

sillä USERMAT-aliohjelmaan ei tule tietoa askeleen alkuhetken lämpötilasta. Tämä voitaisiin kiertoteitse hoitaa varastoimalla edellisen askeleen lopputilan lämpötila sisäisten 
muuttujien taulukkoon. Tässä sitä ei kuitenkaan ole tehty. Termin (116) poisjättö saattaa hidastaa paikallisen iteraation suppenemista tapauksissa, joissa kimmoisten ominaisuuksien muutos aika-askeleella on suuri.

Epälineaarinen evoluutioyhtälösysteemi (114)-(115) ratkaistaan implisiitisellä Eulerin menetelmällä yhdistettynä Newtonin linearisointimenetettelyyn ${ }^{8}$, joka johtaa lineaariseen yhtälösysteemiin

$$
\left[\begin{array}{ll}
\boldsymbol{H}_{11} & \boldsymbol{h}_{12} \\
\boldsymbol{h}_{21} & H_{22}
\end{array}\right]\left\{\begin{array}{c}
\delta \boldsymbol{\sigma} \\
\delta \omega
\end{array}\right\}=\Delta t\left\{\begin{array}{c}
\boldsymbol{f}_{\sigma} \\
f_{\omega}
\end{array}\right\}-\left\{\begin{array}{c}
\Delta \boldsymbol{\sigma} \\
\Delta \omega
\end{array}\right\}
$$

jossa

$$
\begin{aligned}
\boldsymbol{H}_{11} & =\boldsymbol{I}-\Delta t \frac{\partial \boldsymbol{f}_{\sigma}}{\partial \boldsymbol{\sigma}}, \\
\boldsymbol{h}_{12} & =-\Delta t \frac{\partial \boldsymbol{f}_{\sigma}}{\partial \omega}, \\
\boldsymbol{h}_{21} & =-\Delta t \frac{\partial f_{\omega}}{\partial \boldsymbol{\sigma}}, \\
H_{22} & =1-\Delta t \frac{\partial f_{\omega}}{\partial \omega} .
\end{aligned}
$$

Aika-integointialgoritmilla diskretoidun epälineaarisen algebrallisen systeemin Jakobin matriisi on muotoa

$$
\boldsymbol{C}^{\mathrm{alg}}=\omega \widetilde{\boldsymbol{H}}_{11}^{-1} \boldsymbol{C}_{\mathrm{e}}
$$

jossa

$$
\widetilde{\boldsymbol{H}}_{11}=\boldsymbol{H}_{11}-\boldsymbol{h}_{12} H_{22}^{-1} \boldsymbol{h}_{21}^{\mathrm{T}} .
$$

Kuten havaitaan, on Jacobin matriisi vauriomuuttujasta johtuen epäsymmetrinen. Oikein muodostettu materiaalimallin integroinnin Jakobin matriisi on välttämätön, jotta globaalissa tasapainoiteraatiossa voitaisiin saavuttaa kvadraattinen konvergenssinopeus käytettäessa Newtonin linearisointimenetelmää.

Implisiittinen Eulerin menetelmä on puhtaan virumisen, plastisen tai viskoplastisen muodonmuutosprosessin integroimisessa hyvä aikaintegrointialgoritmi, erityisesti, jos aikaaskeleen pituus on suuri $[7,20]$. Lähteissä $[7,20]$ on myös havaittu, että epäjatkuva Galerkinin menetelmä, $\mathrm{dG}(1)$, toimii erinomaisesti integroitaessa plastisia tai viskoplastisia materiaalimalleja kytkettynä vaurion evoluutioon. Menetelmän haittapuolena on sen vaatima työmäärä, joka aika-askelta kohden on kaksinkertainen yksiaskeliseen implisiittiseen Eulerin menetelmään verrattuna. Numeeriset esimerkit osoittavat kuitenkin dG(1)menetelmän olevan kilpailukykyinen Eulerin menetelmään verrattuna, sillä se mahdollistaa usein suuremman aika-askeleen käytön tarkkuuden siitä kärsimättä. Tässä artikkelissa ei kuitenkaan ole sovellettu epäjatkuvia Galerkinin menetelmiä.

\section{Esimerkki}

Tarkastellaan tyypillisen T24 teräksestä tehdyn tulistimen ( $\varnothing 355.6 \mathrm{~mm} \times 36 \mathrm{~mm}$ ) ja aisaputken liitoksen virumisväsymisanalyysiä, jossa operaatiolämpötila on 500:n ja 600:n celcius-asteen välillä [18]. Rakenteen kuormituksena on sisäinen vakiopaine 14.0 $\mathrm{MPa}(\mathrm{g})$, ja ajan suhteen muuttuva lämpötila ja siirtymä aisaputken $\varnothing 44.5 \mathrm{~mm} \times 6.3 \mathrm{~mm}$ päässä,

${ }^{8}$ Symbolit $\Delta$ ja $\delta$ viittaavat inkrementaalisiin ja iteratiivisiin muutoksiin: $\boldsymbol{\sigma}_{n}^{i+1}=\boldsymbol{\sigma}_{n}^{i}+\delta \boldsymbol{\sigma}_{n}^{i}, \Delta \boldsymbol{\sigma}_{n}^{i}=$ $\boldsymbol{\sigma}_{n}^{i}-\boldsymbol{\sigma}_{n-1}$, jossa alaindeksi viittaa aika-askeleeseen ja yläindeksi Newtonin iteraatioaskeleeseen. 

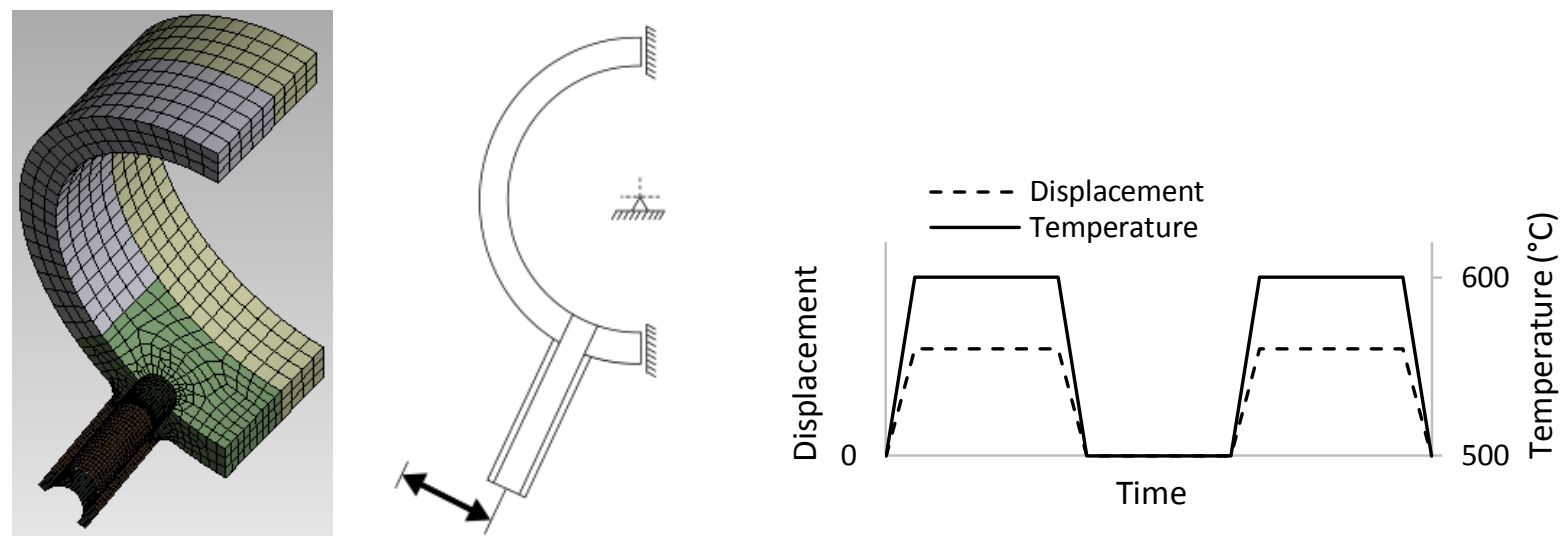

Kuva 16. Käytetty elementtiverkko koostuu pääosin 20 solmuisista heksaedrielementeistä ANSYS SOLID186 ja joistain 10 solmuisista tetraedrielementeistä SOLID187. Siirtymäreunaehtohistoria putken suuttimen päässä. Siirtymä ja lämpötila muuttuvat ajan suhteen periodisesti [18].

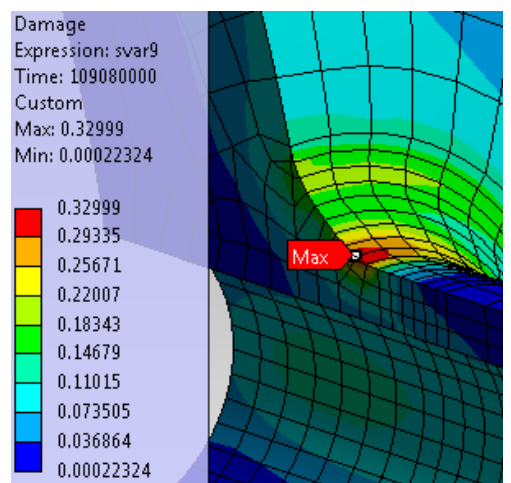

(a)

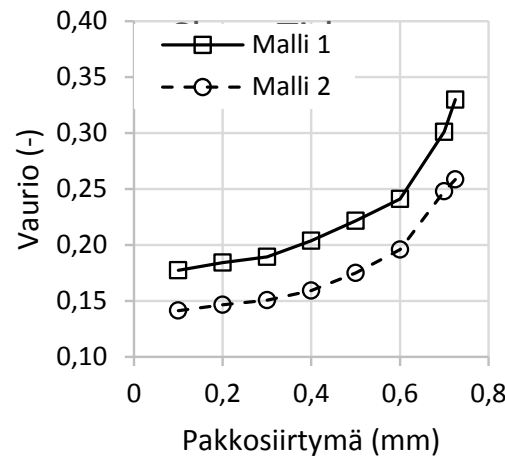

(b)

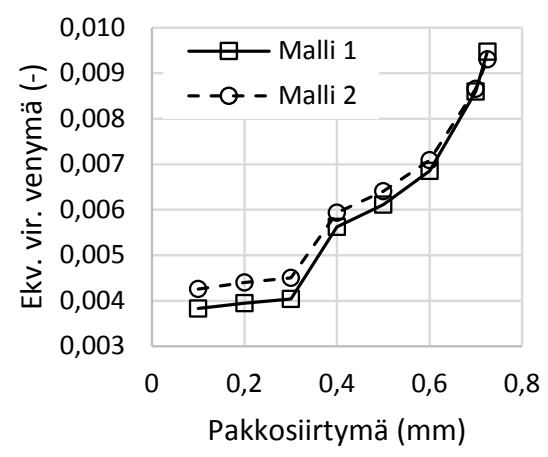

(c)

Kuva 17. (a) Vaurion jakautuminen putkiyhteen rasitetuimman kohdan ympäristössä. (b) Vaurion ja (c) ekvivalentin virumisvenymän kehittyminen rasitetuimmassa kohdassa pakkosiirtymän funktiona [18].

katso kuvaa 16. Pakkosiirtymä mallintaa tulistimen lämpömuodonmuutoksista aiheutuvia rasituksia. Kimmokertoimen lämpötilariippuvuus oletetaan lineaariseksi seuraavien arvoparien välillä: $175 \mathrm{MPa}$ lämpötilassa $500^{\circ} \mathrm{C},\left(168 \mathrm{MPa}, 550^{\circ} \mathrm{C}\right)$ sekä $\left(163 \mathrm{MPa}, 600^{\circ} \mathrm{C}\right)$ [2]. Poissonin vakio otaksutaan yksinkertaisuuden vuoksi lämpötilasta riippumattomaksi ja analyysissä on käytetty arvoa $\nu=0.3$ [18].

Analyysin päätulokset on esitetty kuvassa 17: vauriokenttä $(D=1-\omega)$ sekä vaurion ja tehollisen virumisvenymän kehittyminen pakkosiirtymän funktiona rasitetuimmassa kohdassa, joka on tulistinputken ja aisan kiinnityskohdan hitsisauman pinnalla. Huomautettakoon, että tässä tehdyssä analyysissä hitsisaumaa ei ole mallinnettu erillisenä vaan sille on oletettu perusmateriaalin parametrit. Mallin 1 havaitaan antavan 3-7 prosenttiyksikköä suurempia vaurion arvoja kuin Monkman-Grant-hypoteesin toteuttava malli 2. Tämän perusteella voitaisiin todeta molempien mallien antavan käytännön mitoituksen perustaksi riittävän tarkkoja tuloksia. Vaikkakin malli 1 tuottaa suuremmat vaurion arvot, tehollisen virumisvenymän arvot ovat miltei identtiset. Mallinnuksen tuloksena rakenteen käyttöiäksi saatiin 150 kuormasykliä. Sykli koostui 200 tunnin pitojaksoista vakiolämpotiloissa $500{ }^{\circ} \mathrm{C}$ ja $600{ }^{\circ} \mathrm{C}$, sekä tunnin mittaisista nosto ja laskuajoista.

Suunnittelunäkökulmasta katsoen molemmat kehitetyistä malleista antoivat käytän- 
nöllisesti yhteneväiset tulokset lämpötila-alueella 500-600 ${ }^{\circ} \mathrm{C}$. Kuitenkin mallin 2 havaittiin tuottavan hieman mallia 1 epätarkempia tuloksia matalemmilla lämpötilan arvoilla, joka on seurausta pakotetusta Monkman-Grant ehdon toteutuksesta. Vaikkakin mallissa 1 on enemmän määritettäviä materiaaliparametreja, on se suositeltavampi virumisväsymisanalyyseissa sen laajemman käyttölämpötila-alueen vuoksi. On myös huomattava, että korkeissa lämpötiloissa se toteuttaa melko hyvin myös Monkman-Grant hypoteesin ehdon.

\section{Loppupäätelmät}

Artikkelissa on esitetty melko yleinen termodynaamisesti konsistentti malli virumisväsymisen analysointiin. Mallin materiaaliparametrit määritettiin 7CrMoVTiB10-10 (T24) teräkselle lämpötila-alueella $500-600^{\circ} \mathrm{C}$. Malli implementoitiin myös ANSYS elementtimenetelmäohjelmiston USERMAT-aliohjelmaksi. Mallia on sovellettu tulistinkammion aisan väsymisanalysointiin.

Virumisvaurion synty puristavan jännityksen alaisena on hitaampaa kuin vetojännityksen alaisena. Vauriomallia voidaan varsin yksinkertaisesti muuttaa siten, että se huomioi erilaiset virumisominaisuudet puristuksessa ja vedossa. Tämä edellyttäisi kuitenkin yhden uuden materiaaliparametrin, jonka määrittämiseen tarvitaan puristusvirumakoe.

Toinen vauriomallin kehitysaihe on anisotrooppisen vauriomuuttujan käyttö isotrooppisen muuttujan sijaan.

Erittäin haastava lisätutkimusaihe olisi muodostaa raetason mikromekaaninen malli lämpökäsittelyvaurioiden analysoimiseksi.

\section{Kiitokset}

Tämä työ on tehty Tekesin tukemassa Flexible Energy Systems (FLEXe) tutkimusohjelmassa, jonka tavoitteena on luoda uusia teknologisia ja liiketaloudellisia konsepteja edesauttamaan nykyisen energiajärjestelmän muutosta kohta kestävän kehityksen systeemiä. FLEXe konsortio koostuu 17 teollisesta ja 10 tutkimusorganisaatiosta. Ohjelmaa koordinoi CLIC Innovation Oy www.clickinnovation.fi.

Haluamme kiittää emeritusprofessori Martti Mikkolaa ja TkT Kari Santaojaa käsikirjoituksen huolellisesta luvusta, kommenteista ja parannusehdotuksista.

\section{Viitteet}

[1] H. Altenbach, Y. Gorash, K. Naumenko. Steady-state creep of a pressurized thick cylinder in both the linear and the power law ranges. Acta Mechanica, 195(1-4): 263-274, 2009. doi:10.1007/s00707-007-0546-5.

[2] J. Arndt, K. Haarmann, G. Kottmann, J. Vaillant, W. Bendick, G. Kubla, A. Arbab, F. Deshayes. The T23/T24 Book. Vallourec \& Mannesmann Tubes, 2nd edition, 2000 .

[3] M. Ashby, H. Shercliff, D. Cebon. Materials: Engineering, Science, Processing and Design. Elsevier, 2 edition, 2010.

[4] J. Betten. Creep Mechanics. Springer-Verlag, Berlin, 2005. 
[5] J.L. Chaboche. A review of some plasticity and viscoplasticity constitutive theories. International Journal of Plasticity, 24(10):1642 - 1693, 2008. doi:10.1016/j.ijplas.2008.03.009. Special Issue in Honor of Jean-Louis Chaboche.

[6] E.N. da Costa Andrade. On the viscous flow in metals, and allied phenomena. Proceedings of the Royal Society A, 84:1-12, 1910.

[7] T. Eirola, J. Hartikainen, R. Kouhia, T. Manninen. Some observations on the integration of inelastic constitutive models with damage. In O. Dahlblom, L. Fuchs, K. Persson, M. Ristinmaa, G. Sandberg, and I. Svensson, editors, Proceedings of the 19th Nordic Seminar on Computational Mechanics, pages 23-32. Division of Structural Mechanics, LTH, Lund University, 2006.

[8] M. Frémond. Non-Smooth Thermomechanics. Springer, Berlin, 2002.

[9] H.J. Frost M.F. Ashby. Deformation-Mechanism Maps: The Plasticity and Creep of Metals and Ceramics. Pergamon Press, 1982. ISBN 9780080293370. URL http: //engineering/darthmouth.edu/defmech/.

[10] F. Garofalo. Fundamentals of Creep and Creep-Rupture in Metals. Macmillan series in Materials Science. Macmillan, New York, 1965.

[11] Y. Gorash. Development of a creep-damage model for non-isothermal long-term strength analysis of high-temperature components operating in a wide stress range. PhD thesis, Martin-Luther-Universität, Halle-Wittenberg, Germany, 2008.

[12] D.R. Hayhurst. Creep rupture under multiaxial states of stress. Journal of Mechanics and Physics of Solids, 20:381-390, 1972. doi:10.1016/0022-5096(72)90015-4.

[13] D.R. Hayhurst. The use of continuum damage mechanics in creep analysis for design. Journal of Strain Analysis, 29(3):233-241, 1994.

[14] J.A.H. Hult. Creep in Engineering Structures. Blaisdell Publishinh Company, 1966.

[15] L.M. Kachanov. On the creep fracture time. Iz. An SSSR Ofd. Techn. Nauk., (8): 26-31, 1958. (in Russian).

[16] L.M. Kachanov. Introduction to continuum damage mechanics, volume 10 of Mechanics of Elastic Stability. Martinus Nijhoff Publishers, 1986.

[17] P. Kauppila. Laskentamenetelmän kehittäminen tulistinkammioiden virumisen ja väsymisen analysointiin. Diplomityö, Tampereen Teknillinen Yliopisto, 2016.

[18] P. Kauppila, R. Kouhia, J. Ojanperä, T. Saksala, T. Sorjonen. A continuum damage model for creep fracture and fatigue analysis. Structural Integrity Procedia, 2:887894, 2016. doi:10.1016/j.prostr.2016.06.114.

[19] J.B. Kitto, S.C. Stultz. Steam: Its generation and Use. The Babcock \& Wilcox Company, 41 edition, 2005.

[20] R. Kouhia, P. Marjamäki, J. Kivilahti. On the implicit integration of inelastic constitutive equations. International Journal for Numerical Methods in Engineering, 62: 1832-1856, 2005. doi:10.1002/nme.1252. 
[21] F.R. Larson, J. Miller. A time-temperature relationship for rupture and creep stresses. Transactions of ASME, 74:765-775, 1952.

[22] J. Larsson. Evaluation of current methods for creep analysis and impression creep testing of power plant steels. Master's thesis, KTH Royal Institute of Technology, Stockholm, Sweden, 2012.

[23] J. Lemaitre. A Course on Damage Mechanics. Springer-Verlag, Berlin, 1992.

[24] J. Lemaitre, J.-L. Chaboche. Mechanics of Solid Materials. Cambridge University Press, 1990.

[25] S. Murakami. Continuum Damage Mechanics, volume 185 of Solid Mechanics and Its Applications. Springer Netherlands, 2012.

[26] F.R.N. Nabarro, H.L. Villers. The Physics of Creep and Creep Resistant Alloys. Taylor \& Francis Ltd., 1995.

[27] K. Naumenko. Modeling of high temperature creep for structural analysis applications. PhD thesis, Martin-Luther-Universität, Halle-Wittenberg, Germany, 2006.

[28] F.K.G. Odqvist. Mathematical Theory of Creep and Creep Rupture. Oxford Mathematical Monographs. Oxford University Press, London, 1966.

[29] N.S. Ottosen, M. Ristinmaa. The Mechanics of Constitutive Modeling. Elsevier, 2005.

[30] R.K. Penny, D.L. Marriott. Design for creep. McGraw-Hill, 1971.

[31] H. Riedel. Fracture at High Temperatures. MRE Materials Reserch and Engineering. Springer-Verlag, Berlin, Heidelberg, 1987.

[32] K. Santaoja. Lecture Notes on Continuum Thermodynamics. Espoo, 2008.

[33] W. Wagner, H.-J. Kretzschmar. International Steam Tables. Springer-Verlag, 2 edition, 2008.

[34] A. Zolochevsky, A. Martynenko, A. Kühhorn. Structural benchmark creep and creep damage testing for finite element analysis with material tension-compression asymmetry and symmetry. Computers and Structures, 100-101:27-38, 2012. doi:10.1016/j.compstruc.2012.02.021.

Petteri Kauppila, Juha Ojanperä, Timo Sorjonen

Valmet Technologies Oy

PL 109, 33101 Tampere

petteri.kauppila@valmet.com, juha.ojanpera@valmet.com, timo.sorjonen@valmet.com

Reijo Kouhia, Timo Saksala

Tampereen teknillinen yliopisto

Rakennustekniikka

PL 600, 33101 Tampere

reijo.kouhia@tut.fi, timo.saksala@tut.fi 